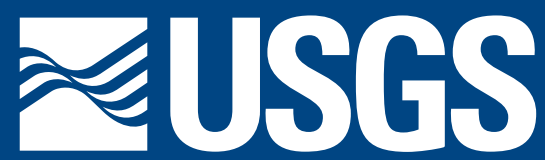

science for a changing world

\title{
Hurricane lke: Observations and Analysis of Coastal Change
}

\section{USGS Open-File Report 2009-1061}

By Kara S. Doran, Nathaniel G. Plant, Hilary F. Stockdon, Asbury H. Sallenger, and Katherine A. Serafin
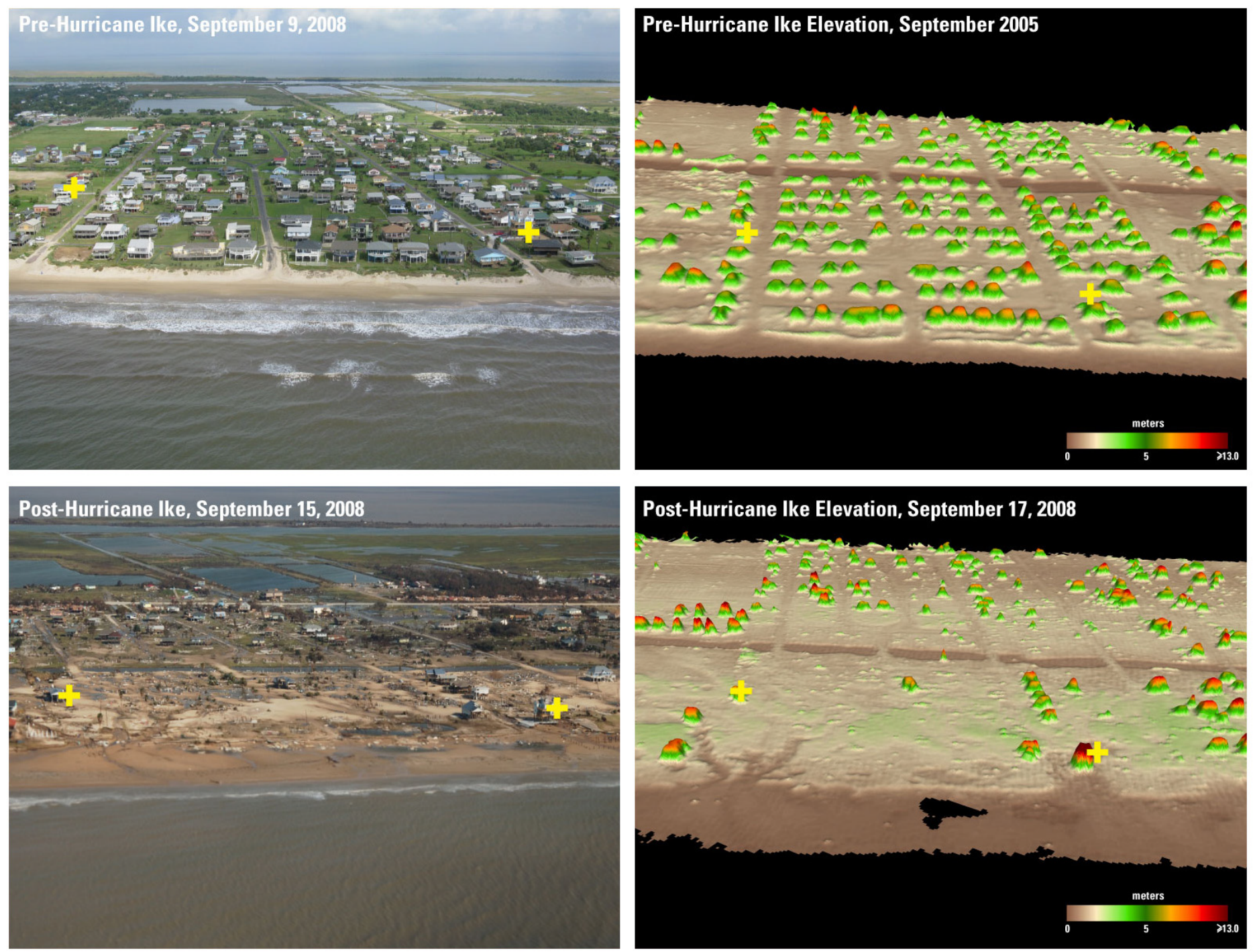



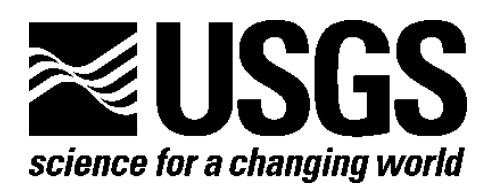

\section{Hurricane lke: Observations and Analysis of Coastal Change}

By Kara S. Doran, Nathaniel G. Plant, Hilary F. Stockdon, Asbury H. Sallenger, and Katherine A. Serafin

Open-File Report 2009-1061

U.S. Department of the Interior

U.S. Geological Survey 


\section{U.S. Department of the Interior \\ KEN SALAZAR, Secretary}

\section{U.S. Geological Survey \\ Suzette M. Kimball, Acting Director}

U.S. Geological Survey, Reston, Virginia 2009

For product and ordering information:

World Wide Web: http://www.usgs.gov/pubprod

Telephone: 1-888-ASK-USGS

For more information on the USGS-the Federal source for science about the Earth,

its natural and living resources, natural hazards, and the environment:

World Wide Web: http://www.usgs.gov

Telephone: 1-888-ASK-USGS

Suggested citation:

Doran, Kara S., Plant, Nathaniel G., Stockdon, Hilary F., Sallenger, Asbury H., Serafin, Katherine A., 2009, Hurricane Ike: Observations of Coastal Change: U.S. Geological Survey Open-File Report 2009-1061.

Any use of trade, product, or firm names is for descriptive purposes only and does not imply endorsement by the U.S. Government.

Although this report is in the public domain, permission must be secured from the individual copyright owners to reproduce any copyrighted material contained within this report. 


\section{Contents}

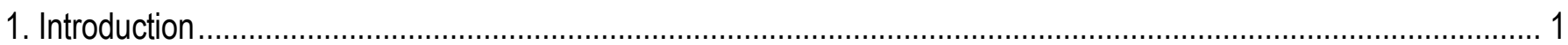

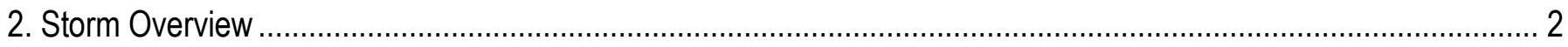

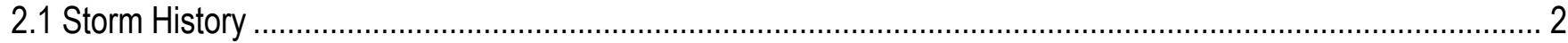

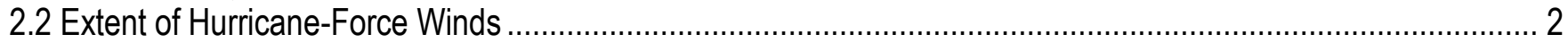

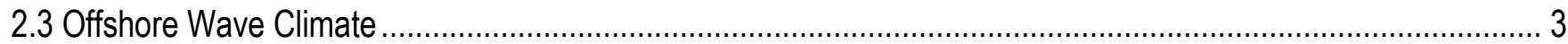

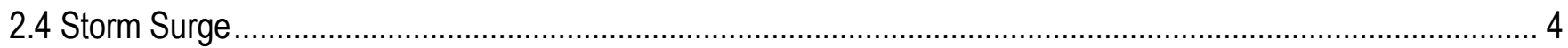

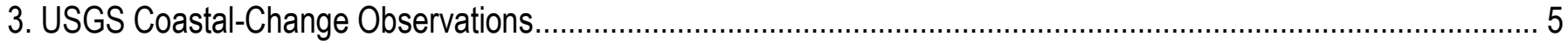

3.1 Oblique Aerial Photography and Video observations ………..................................................................

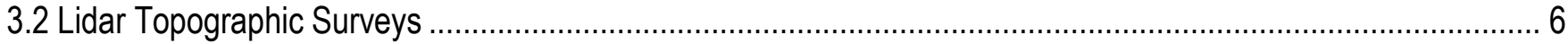

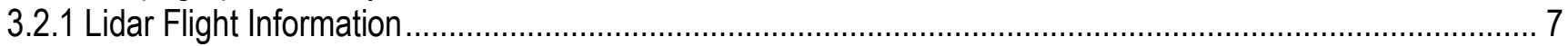

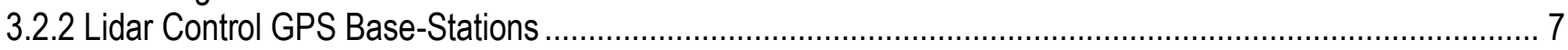

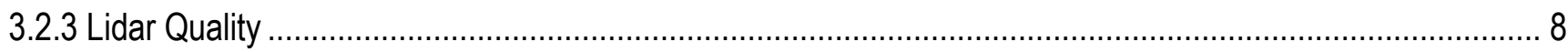

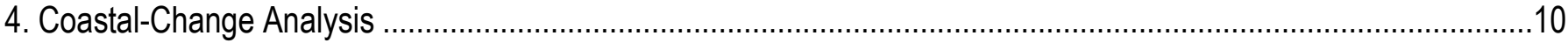

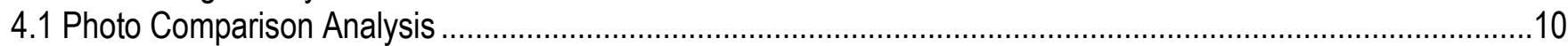

4.1.1 Surfside Beach to San Luis Pass, Texas.....................................................................................

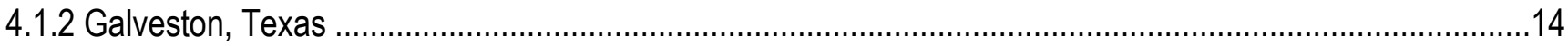

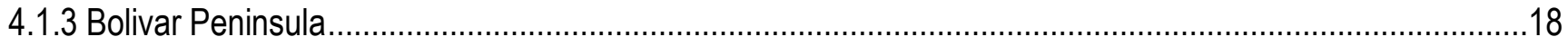

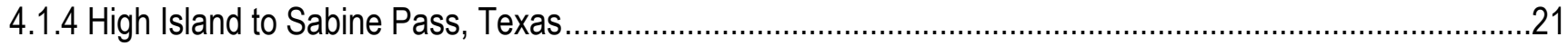

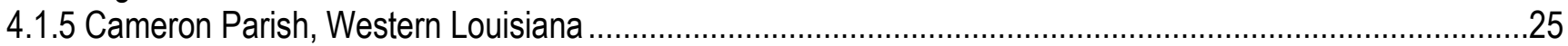

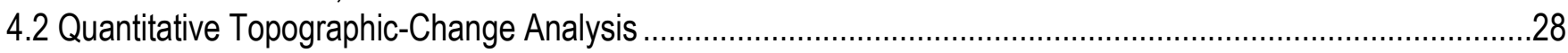

4.2.1 Dune Elevation Change..............................................................................................................

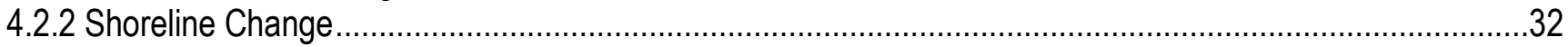

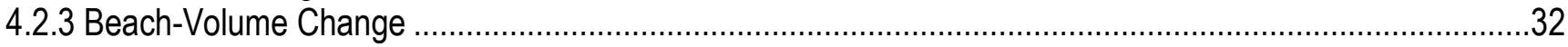

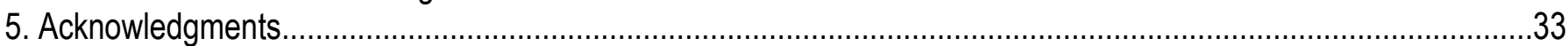

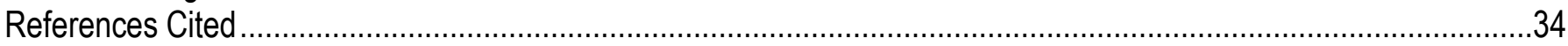

\section{Figures}

Figure 1. Track of Hurricane Ike in the Atlantic Ocean, Caribbean Sea, and Gulf of Mexico. …........................... 2

Figure 2. Wind speeds in kilometers per hour generated by Hurricane lke, as calculated by the National Oceanic and Atmospheric Administration Hurricane Research Division.

Figure 3. Significant wave height during the passage of Hurricane Ike, as measured from National Oceanic and Atmospheric Administration Buoy 42035 located near Galveston, Texas..................................................... 4

Figure 4. Digital-photography and video and recording system used aboard aircraft during coastal oblique video and

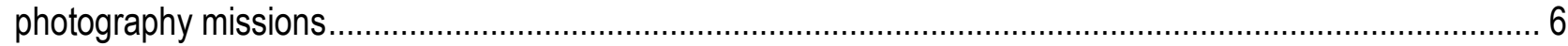

Figure 5. Hurricane lke pre- and post-storm oblique aerial photography and video flights and post-storm lidar

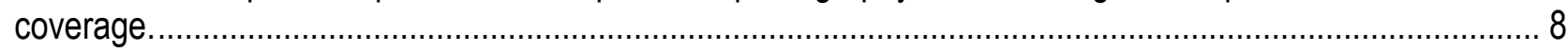

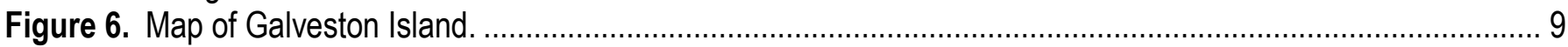

Figure 7. Relative offset between 2005 and 2008 Experimental Advanced Airborne Research Lidar first-return

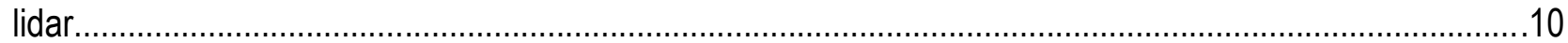

Figure 8. Location index for photo pairs from Surfside Beach, Texas to Cameron Parish, Louisiana....................11

Figure 9. Oblique aerial photography from Quintana, Texas, on September 9, 2008 and September 15, 2008, two days after landfall of Hurricane lke

Figure 10. Oblique aerial photography from Christmas Bay, Texas, on September 9, 2008, and September 15, 2008, two days after landfall of Hurricane lke. 
Figure 11. Oblique aerial photography of Galveston, Texas, on September 9, 2008, and September 15, 2008, two days after landfall of Hurricane Ike

Figure 12. Oblique aerial photography of Galveston, Texas, on September 9, 2008, and September 15, 2008, two days after landfall of Hurricane lke

Figure 13. Oblique aerial photography of Galveston, Texas, on September 9, 2008, and September 15, 2008, two days after landfall of Hurricane lke

Figure 14. Oblique aerial photography of Bolivar Peninsula, Texas, on September 9, 2008, and September 15, 2008, two days after landfall of Hurricane lke

Figure 15. Oblique aerial photography of Bolivar Peninsula, Texas, on September 9, 2008, and September 15, 2008, two days after landfall of Hurricane lke.

Figure 16. Oblique aerial photography near McFaddin Wildlife Refuge, Texas, on September 9, 2008, and September 15, 2008, two days after landfall of Hurricane Ike

Figure 17. Oblique aerial photography near McFaddin Wildlife Refuge, Texas, on September 9, 2008, and September 15, 2008, two days after landfall of Hurricane Ike

Figure 18. Oblique aerial photography near McFaddin Wildlife Refuge, Texas, on September 9, 2008, and September 15, 2008, two days after landfall of Hurricane lke

Figure 19. Oblique aerial photography from Cameron Parish, Louisiana, on September 9, 2008, and September 15, 2008, two days after landfall of Hurricane lke

Figure 20. Oblique aerial photography from Peveto Beach, Louisiana, on September 9, 2008, and September 15, 2008, two days after landfall of Hurricane lke.

Figure 21. Oblique aerial photography from Holly Beach, Louisiana, from 2001-2008.

Figure 22. September 2005 Experimental Advanced Airborne Research Lidar first-return lidar digital elevation model of Crystal Beach, Texas.

Figure 23. September 2008 Experimental Advanced Airborne Research Lidar first-return lidar digital elevation model of Crystal Beach, Texas.

Figure 24. Coastal change at Crystal Beach, Texas due to Hurricane lke. 31

Figure 25. Hurricane lke dune-elevation change, shoreline change, and beach-volume change. 33

\section{Tables}

Table 1. Details of the two GPS control stations used during the September 17-18, 2008, EAARL lidar mission...7 


\section{Conversion Factors}

Vertical coordinate information is referenced to the North American Vertical Datum of 1988 (NAVD 88).

Horizontal coordinate information is referenced to the North American Datum of 1983 (NAD 83).

Altitude, as used in this report, refers to distance above the vertical datum.

SI to Inch/Pound

\begin{tabular}{lcl}
\hline \multicolumn{1}{c}{ Multiply } & By & \multicolumn{1}{c}{ To obtain } \\
\hline centimeter $(\mathrm{cm})$ & Length & \\
meter $(\mathrm{m})$ & 0.3937 & inch (in.) \\
kilometer $(\mathrm{km})$ & 3.281 & foot $(\mathrm{ft})$ \\
kilometer $(\mathrm{km})$ & 0.6214 & mile (mi) \\
meter $(\mathrm{m})$ & 0.5400 & mile, nautical $(\mathrm{nmi})$ \\
\hline & 1.094 & yard $(\mathrm{yd})$ \\
\hline cubic meter $\left(\mathrm{m}^{3}\right)$ & Volume & \\
cubic meter $\left(\mathrm{m}^{3}\right)$ & 6.290 & barrel $($ petroleum, 1 barrel = 42 gal) \\
cubic meter $\left(\mathrm{m}^{3}\right)$ & 264.2 & gallon (gal) \\
cubic decimeter $\left(\mathrm{dm}^{3}\right)$ & 0.0002642 & million gallons $(\mathrm{Mgal})$ \\
cubic meter $\left(\mathrm{m}^{3}\right)$ & 0.03531 & cubic foot $\left(\mathrm{ft}^{3}\right)$ \\
cubic meter $\left(\mathrm{m}^{3}\right)$ & 35.31 & cubic foot $\left(\mathrm{ft}^{3}\right)$ \\
& 1.308 & cubic yard $\left(\mathrm{yd}{ }^{3}\right)$ \\
\hline kilometer per hour $(\mathrm{km} / \mathrm{hr})$ & Flow rate & \\
\hline
\end{tabular}

\section{Additional Abbreviations and Acronyms}

DEFINITION

CORS

DEM

EAARL

GPS

$\mathrm{Hz}$
Continuously Operating Reference Stations

Digital Elevation Model

Experimental Advanced Airborne Research Lidar

Global Positioning System

Hertz 


\begin{tabular}{ll}
\hline kHz & Kilohertz \\
KGLS & Scholes International Airport at Galveston \\
KPKV & Calhoun County Airport \\
Lidar & Light Detection and Ranging \\
NAD83 & North American Datum 1983 \\
NAVD88 & North American Vertical Datum 1988 \\
NHC & National Hurricane Center \\
nm & Nanometer(s) \\
NOAA & National Oceanic and Atmospheric \\
NWC & Administration \\
USGS & National Weather Center \\
UTC & U.S. Geological Survey \\
& Coordinated Universal Time \\
\hline
\end{tabular}




\title{
Hurricane Ike: Observations and Analysis of Coastal Change
}

\author{
By Kara S. Doran, Nathaniel G. Plant, Hilary F. Stockdon, Asbury H. Sallenger, and Katherine A. Serafin
}

\section{Introduction}

Understanding storm-induced coastal change and forecasting these changes require knowledge of the physical processes associated with the storm and the geomorphology of the impacted coastline. The primary physical processes of interest are the wind field, storm surge, and wave climate. Not only does wind cause direct damage to structures along the coast, but it is ultimately responsible for much of the energy that is transferred to the ocean and expressed as storm surge, mean currents, and large waves. Waves and currents are the processes most responsible for moving sediments in the coastal zone during extreme storm events. Storm surge, the rise in water level due to the wind, barometric pressure, and other factors, allows both waves and currents to attack parts of the coast not normally exposed to those processes.

Coastal geomorphology, including shapes of the shoreline, beaches, and dunes, is equally important to the coastal change observed during extreme storm events. Relevant geomorphic variables include sand dune elevation, beach width, shoreline position, sediment grain size, and foreshore beach slope. These variables, in addition to hydrodynamic processes, can be used to predict coastal vulnerability to storms.

The U.S. Geological Survey's (USGS) National Assessment of Coastal Change Hazards Project (http://coastal.er.usgs.gov/hurricanes), strives to provide hazard information to those interested in the Nation's coastlines, including residents of coastal areas, government agencies responsible for coastal management, and coastal researchers. As part of the National Assessment, observations were collected to measure coastal changes associated with Hurricane Ike, which made landfall near Galveston, Texas, on September 13, 2008. Methods of observation included aerial photography and airborne topographic surveys. This report documents these data-collection efforts and presents qualitative and quantitative descriptions of hurricane-induced changes to the shoreline, beaches, dunes, and infrastructure in the region that was heavily impacted by Hurricane Ike.

The contents of this report are divided into the following sections:

Section 2, Storm Overview - presents a synopsis of the storm, including meteorological evolution, wind speed impact area, wind-wave generation, and storm-surge extent and magnitudes.

Section 3, Coastal-Change Observations - describes the observation missions that responded to Hurricane Ike, which included acquisition of oblique aerial photography and airborne topography surveys using lidar.

Section 4, Coastal-Change Analysis - describes data-analysis methods and results. 


\section{Storm Overview}

\subsection{Storm History}

According to the National Oceanic and Atmospheric Administration (NOAA) National Hurricane Center's best track, Hurricane Ike was an active tropical-weather system in the Caribbean Sea and Gulf of Mexico from August 28 to September 13, 2008 (fig. 1; Berg, 2009). On September 1 at 0600 Universal Time Coordinated (UTC), a tropical wave 1,250 km west of the Cape Verde Islands was identified as a tropical depression. At 1200 UTC the same day, Tropical Storm Ike became the ninth named storm of the 2008 hurricane season. By 0600 UTC on September 4, Ike had intensified to a category 4 storm with winds of $231 \mathrm{~km} / \mathrm{hr}$. Hurricane Ike passed over Grand Turk, Salt Cay, and South Caicos islands on September 7 and made another landfall later that day on Great Inagua Island in the southern Bahamas. Subsequent landfalls occurred near Cabo Lucrecia, Cuba, on September 8 and near San Cristobal, Cuba, on September 9 before the storm entered the Gulf of Mexico. Hurricane Ike crossed the Gulf of Mexico and made landfall along the north end of Galveston Island, Texas, as a strong category 2 storm with maximum sustained winds of $175 \mathrm{~km} / \mathrm{hr}$ at 0700 UTC on September 13 (Berg, 2009).

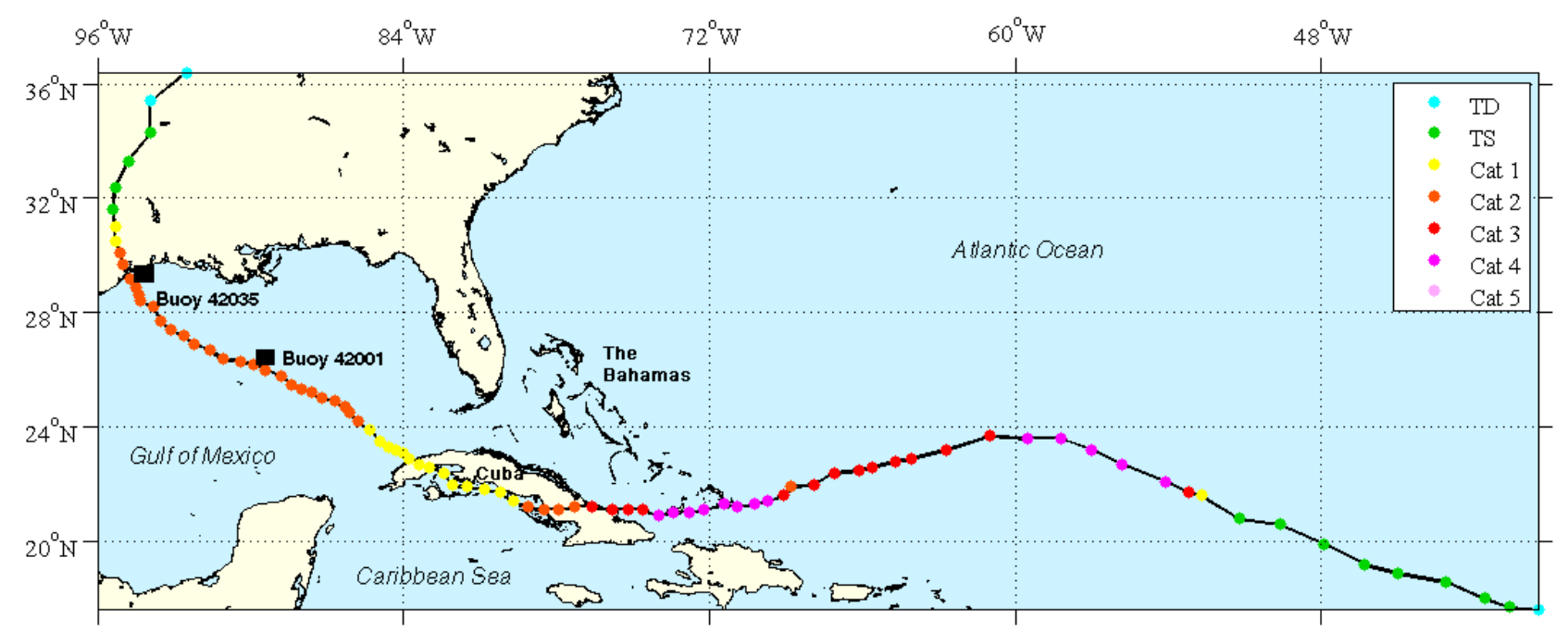

Figure 1. Track of Hurricane Ike in the Atlantic Ocean, Caribbean Sea, and Gulf of Mexico. Hurricane track information was obtained from the National Hurricane Center (Berg, 2009).

\subsection{Extent of Hurricane-Force Winds}

Maximum sustained wind swaths estimated by the NOAA Atlantic Oceanographic and Meteorological Laboratory Hurricane Research Division (using methods described by Powell and others, 1998) indicate that hurricane-force winds impacted approximately $180 \mathrm{~km}$ of coastline (Fig. 2). The maximum wind-speeds were observed just east of Galveston, Texas. Hurricane-force winds extended across the Texas-Louisiana border and affected much of the Louisiana coast. 


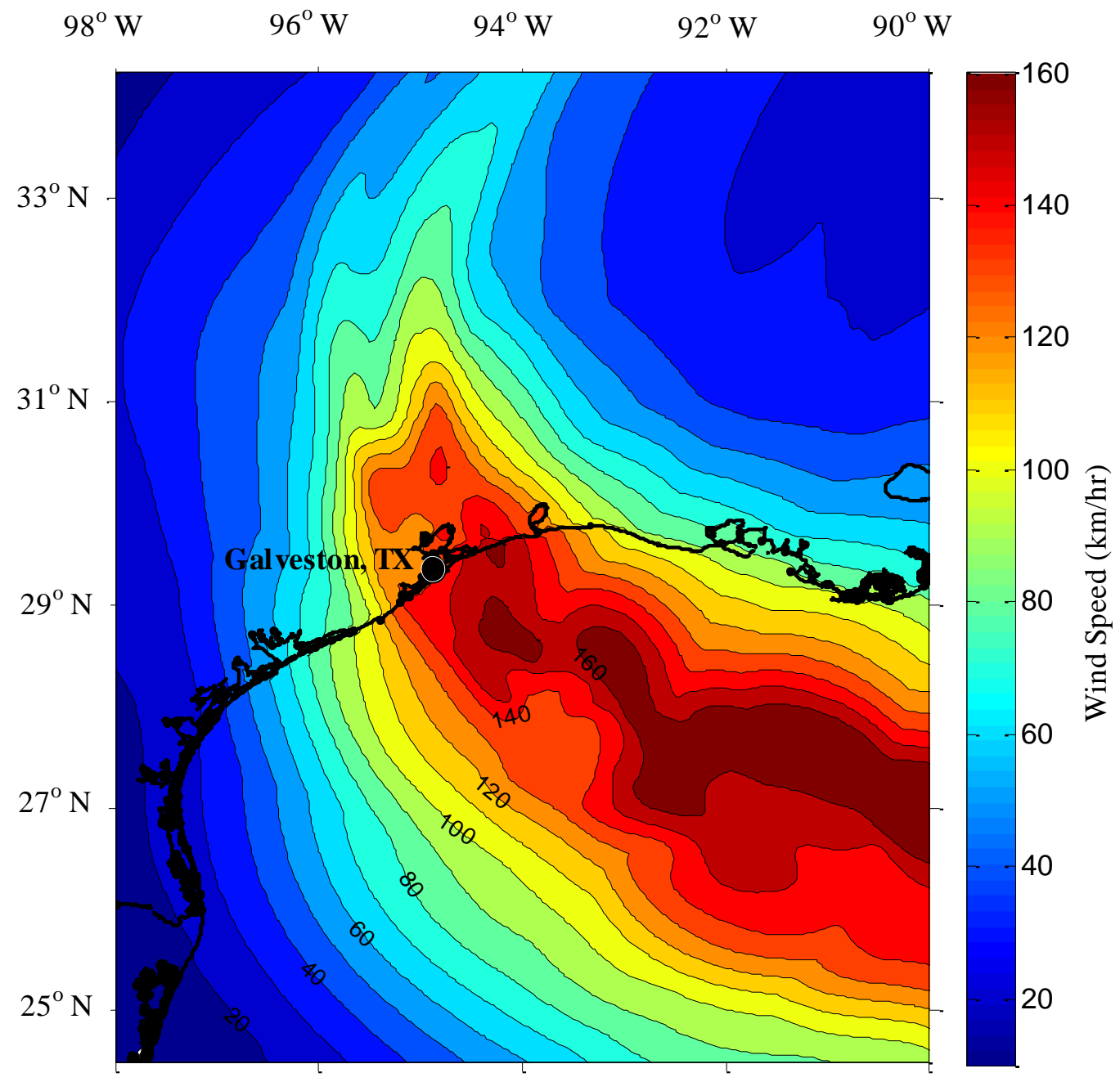

Figure 2. Wind speeds in kilometers per hour generated by Hurricane Ike, as calculated by the National Oceanic and Atmospheric Administration Hurricane Research Division. The extent of hurricane-force wind, as defined by a category 1 wind speed of $119 \mathrm{~km} / \mathrm{hr}$, is indicated by the orange contour.

\subsection{Offshore Wave Climate}

Several moored buoys operated by the NOAA National Data Buoy Center recorded heights and periods of waves generated by Hurricane Ike. Approximately $33 \mathrm{hrs}$ prior to landfall, Hurricane Ike passed within $28 \mathrm{~km}$ of Buoy 42001 (fig. 1), which is located in the Gulf of Mexico approximately 330 $\mathrm{km}$ south of Southwest Pass, Louisiana. The maximum significant wave height recorded at this station was 9.2 m (National Data Buoy Center, 2008). Buoy 42035 (fig. 1), moored east of Galveston, Texas, in $13.7 \mathrm{~m}$ of water, went adrift on September 12 and later passed through the eye of Hurricane Ike. The buoy recorded a maximum significant wave height of $6.0 \mathrm{~m}$ at 0400 UTC on September 13 (fig. 3 ), 3 hrs before Hurricane Ike came ashore in Galveston, Texas (National Data Buoy Center, 2008). 


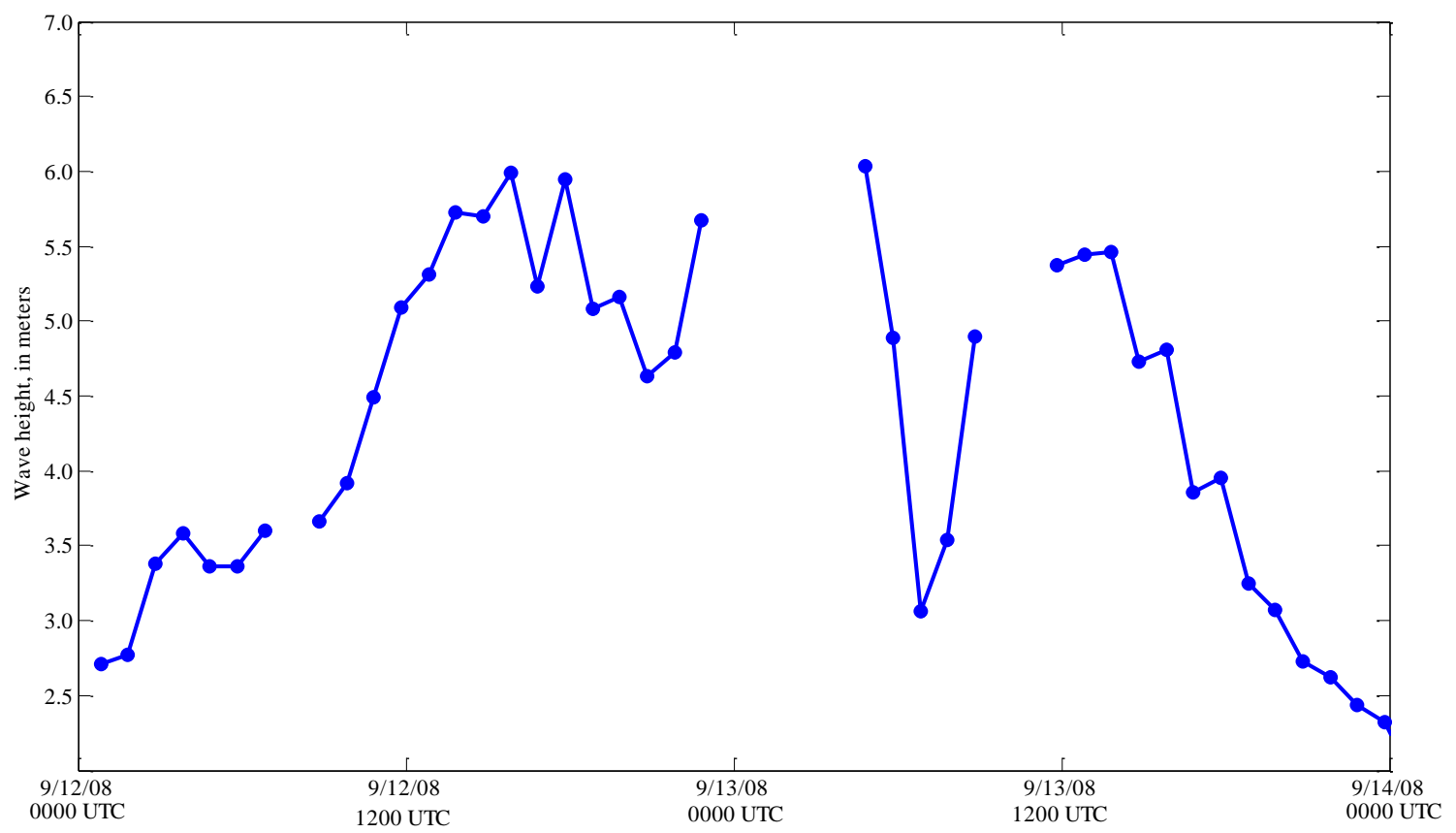

Figure 3. Significant wave height during the passage of Hurricane lke, as measured from National Oceanic and Atmospheric Administration Buoy 42035 located near Galveston, Texas.

\subsection{Storm Surge}

Measurements of maximum storm surge are generally gathered from coastal tide gages and landbased storm sensors (East and others, 2008), and high-water marks (McGee and others, 2006). During Hurricane Ike, many tide gages were operational, and the data have been published by NOAA (Berg, 2009; National Weather Service Houston/Galveston, 2008). Higher-than-normal water levels affected all Gulf Coast States as Hurricane Ike moved into the Gulf of Mexico. The large wind field pushed water toward the coastline well before landfall. Maximum storm tides ranged from 0.37 to $0.87 \mathrm{~m}$ above normal along the west coast of Florida. The coasts of Alabama, Mississippi, and southeastern Louisiana experienced maximum storm surges ranging from $0.79 \mathrm{~m}$ at Gulfport, Mississippi, to $1.98 \mathrm{~m}$ at Shell Beach near New Orleans, Louisiana. West of Grand Isle, Louisiana, storm-surge heights rose progressively, increasing from $1.17 \mathrm{~m}$ at Grand Isle to $3.82 \mathrm{~m}$ at Port Arthur, Texas. Near landfall, many tide gages failed due to large wave action that destroyed the instrument platforms. On the Bolivar Peninsula, high-water marks indicate that all of the area was covered by at least $1 \mathrm{~m}$ of water with many areas covered by at least $3 \mathrm{~m}$ of water (Berg, 2009). Storm-surge levels on Galveston Island are estimated to have been between 3 and $4.5 \mathrm{~m}$ from high-water marks and the Eagle Point tide gage, located in Galveston Bay. South of Galveston Island along the Texas coast in Brazoria County, surge levels of 1.5 to $3 \mathrm{~m}$ were recorded. 


\section{USGS Coastal-Change Observations}

The USGS National Assessment of Coastal Change Hazards Project responded to Hurricane Ike with the following observation missions:

Pre-storm oblique aerial photography (completed September 10, 2008)

Post-storm oblique aerial photography (completed September 15, 2008)

Post-storm airborne lidar topographic survey (completed September 18, 2008)

Ground-based control surveys (completed September 18, 2008)

The near-real-time response of this effort is documented at http://coastal.er.usgs.gov/hurricanes/ike/.

Photographs taken after the storm are matched to pre-storm images to locate areas of extreme erosion and accretion, retreat of the shoreline, and damage to infrastructure. In some areas of special concern, repeat photography surveys are flown, allowing a closer look at the gradual recovery of the beach system. Additionally, aerial photographs are often valuable for the identification of buildings and vegetation that are not easily distinguished in lidar maps. Post-storm photos are used to plan lidar mapping missions to target areas with significant coastal change. The post-storm topographic-lidar survey targets the region that was heavily affected by the storm. The updated topography from this mission can be compared to pre-storm topography to estimate changes in shoreline position, dune elevation, and infrastructure. The post-storm topography also serves as an update for emergency and coastal managers who require detailed knowledge of the post-storm landscape.

\subsection{Oblique Aerial Photography and Video Observations}

The USGS oblique digital photography is collected prior to hurricane landfall and immediately after landfall. Pre-storm photography is conducted well before landfall or immediately prior to landfall if prior imagery does not exist or is excessively out of date. Digital photography is shot by hand while video is recorded continuously. Images are geolocated using accurate Global Positioning System (GPS) positions which are recorded separately and merged with the imagery in post-processing. The compact digital video/digital photo system (fig. 4) can be used on various aircraft such as the NOAA Twin Otter, the Coast Guard H60 and H65 helicopters, and commercial King Air and Navajo Chieftain aircraft.

A pre-storm oblique aerial-photography survey of the Texas coastline was collected on September 9, 2008, four days before landfall, in a cooperative agreement between Louisiana State University, the University of New Orleans, and the USGS. The aircraft was a single-engine Cessna. In total, 1,767 digital photos were obtained over a 630-km extent from Cameron, Louisiana, to Port Isabel, Texas.

Post-storm oblique aerial photography and video of the region of landfall were collected from a twin engine King Air aircraft on September 14 and 15, 2008, two days after landfall. In total, 2,521 digital photographs and $8 \mathrm{hrs}$ of video were obtained over a $240-\mathrm{km}$ extent from Freeport, Texas, to Cameron, Louisiana. The photography sample rate was 0.5 frames/sec (or approximately 1 photo per $200 \mathrm{~m}$ ). Examples of both pre- and post-storm photographs obtained during these two flights are shown in Section 4.1. 


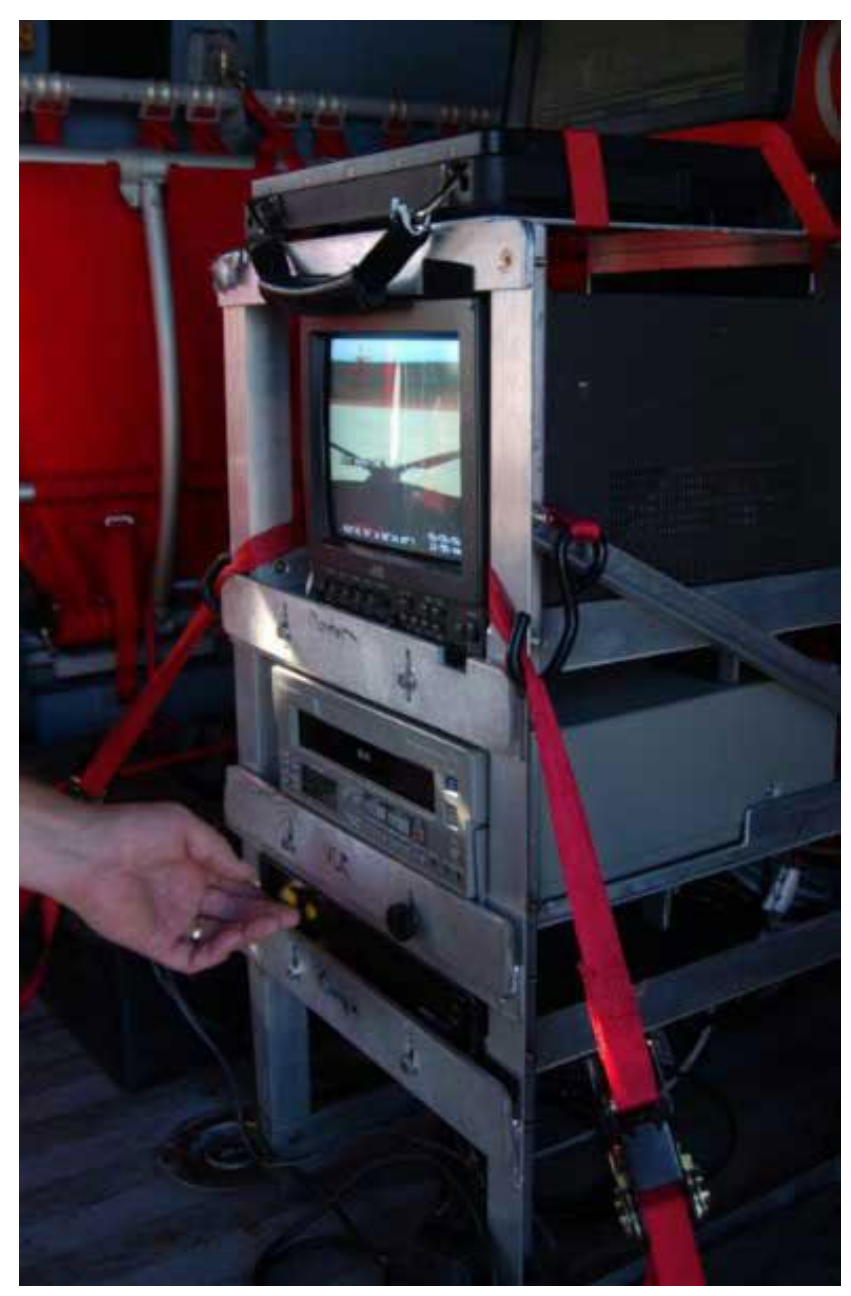

Figure 4. Digital-photography and video recording system used aboard aircraft during coastal oblique video and photography missions.

\subsection{Lidar Topographic Surveys}

Modern, high-resolution lidar systems can map hundreds of kilometers of coast in a day with point densities exceeding one point per square meter. High point densities combined with reasonable horizontal and vertical accuracies allow for the creation of topographic/bathymetric digital-elevation models (DEM) that show details of the coastal environment. Lidar systems emit pulses of light that reflect off the Earth's surface, allowing the computation of elevation from the two-way transmission time. The high-frequency pulses are emitted from a laser that is mounted on a small aircraft. Aircraft movement is monitored by an inertial navigation unit, a GPS unit, and tilt sensors. More complete descriptions of coastal lidar instruments and methods can be found in Brock and others (2002).

Lidar surveys receive positioning control using differential GPS that requires a base-station receiver on the ground. The USGS sets up base stations near the area of hurricane impact if continuously operating reference stations (CORS) are not available. Additionally, because slowly varying positioning errors can corrupt the data (Sallenger and others, 2003), control points are surveyed 
for use in identifying these errors. Control points on surfaces that do not vary, such as roads or parking lots, can be obtained using ground-based surveying methods or by utilizing previous lidar surveys. Ground-based surveys performed on the beach surface are required to be synchronous with the lidar survey because of the likelihood for rapid and significant changes associated with the storm and the post-storm recovery period. Vertical accuracy of the lidar survey data is expected to be on the order of $10-20 \mathrm{~cm}$ (Sallenger and others, 2003), whereas the horizontal-position accuracy is on the order of $1 \mathrm{~m}$ (Nayegandhi and others, in press).

After collection, the lidar data are processed using software specific to the lidar instrument. Included in the processing steps are removal of wild points and separation of points into first- and lastreturn lidar products (Bonisteel and others, in press). The lidar first- and last-returns are the first and last backscatter to return to the sensor from the laser pulse. First-returns can be used to estimate canopy height in vegetated areas or rooftop height in developed areas, while last-returns can be used to estimate elevation of the bare-Earth surface under vegetation.

\subsubsection{Lidar Flight Information}

An airborne lidar survey of post-storm topography was completed September 17, 2008, four days after landfall, on the Texas coast between Port Lavaca and Port Arthur using the USGS Experimental Advanced Airborne Research Lidar (EAARL) system. The EAARL system was mounted on a twin-engine Cessna 310 aircraft. The survey covered $300 \mathrm{~km}$ of coastline in $6.15 \mathrm{hrs}$ and collected 53.5 million points. Eight flight passes were flown from San Luis Pass north to Port Arthur (fig. 5), while only two passes were flown from San Luis Pass south to Port Lavaca. Each pass overlaps the adjacent pass by 30-50 percent. Lidar data were only collected for September 17, 2008. Problems with the laser on September 18 limited the mission to imagery only.

\subsubsection{Lidar Control GPS Base-Stations}

Ground-based survey systems were set up near the airport at Port Lavaca, TX (KPKV) and on the Bolivar Peninsula (KGLS) (fig. 5). New control points were created for both survey locations. Instrumentation details and precise locations, including ellipsoidal height, for each station are listed in table 1. In standby, when the lidar aircraft was not deployed, both GPS systems collected $30 \mathrm{sec}$ data from 2008-09-17 16:28:14 to 2008-09-18 20:52:54. During flights, the sample rate was increased to 2 Hz. GPS quality was good for both stations.

Table 1. Details of the two GPS control stations used during the September 17-18, 2008, EAARL lidar mission.

\begin{tabular}{lll}
\hline Station ID & KPKV & KGLS \\
Latitude & $28^{\circ} 39.1288^{\prime} \mathrm{N}$ & $29^{\circ} 21.7366^{\prime} \mathrm{N}$ \\
Longitude & $96^{\circ} 40.9334^{\prime} \mathrm{W}$ & $94^{\circ} 46.6855^{\prime} \mathrm{W}$ \\
Ellipsoidal Height (WGS84) & $-17.521 \mathrm{~m}$ & $-24.6750 \mathrm{~m}$ \\
Receiver Type & Ashtech Z Eurocard & Ashtech Z Eurocard \\
Antenna Type & ASH700936B_M & ASH700936A_M \\
\hline
\end{tabular}




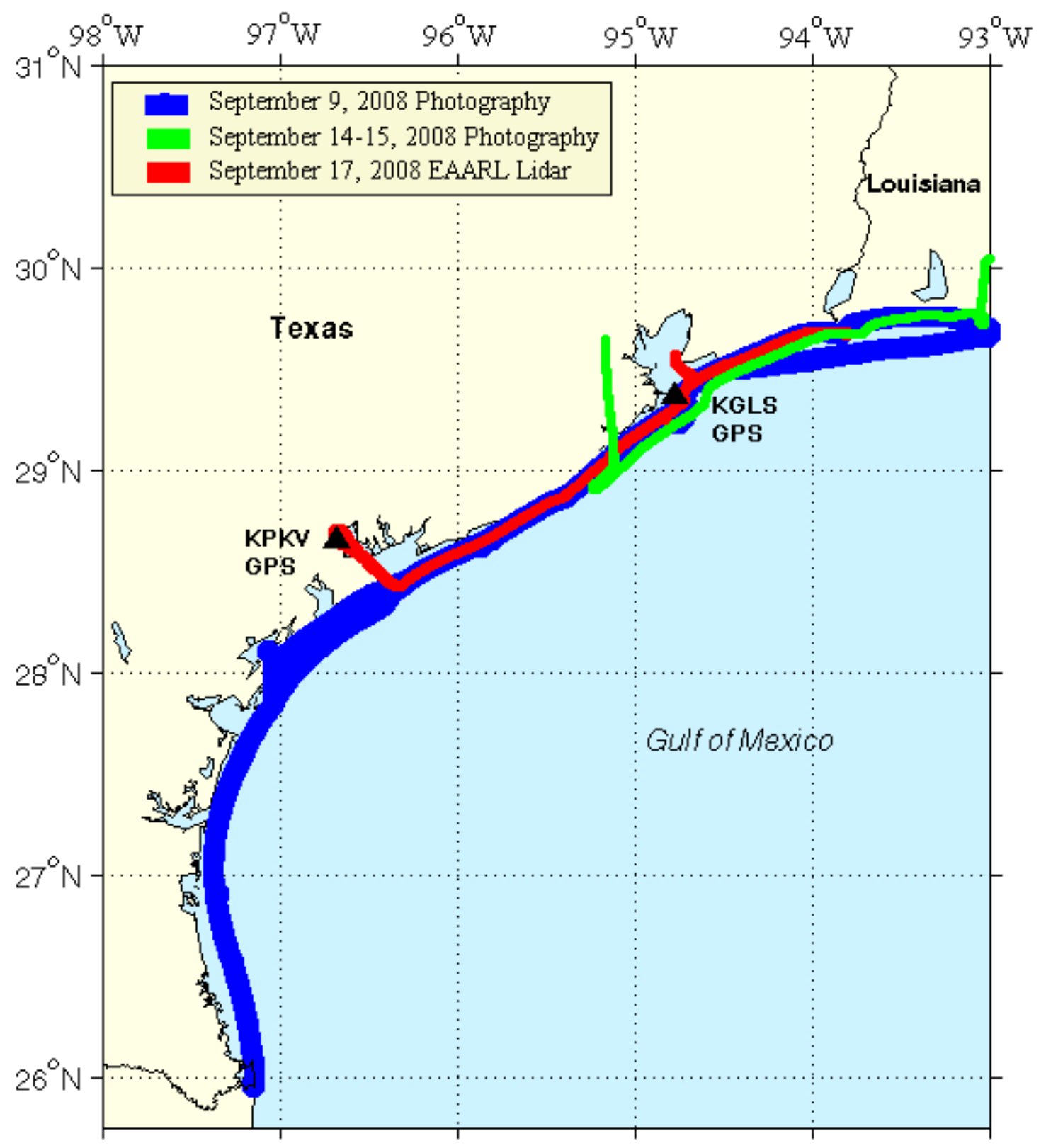

Figure 5. Hurricane lke pre- and post-storm oblique aerial photography and video flights and post-storm lidar coverage. The locations of the GPS base stations are noted as black triangles.

\subsubsection{Lidar Quality}

First-return lidar points were interpolated to a series of regular 5 x $5 \mathrm{~m}$ grid domains. The interpolation method applies a smoothing filter that removes short-scale variability and determines the degree to which residual noise has been removed. Elevations at grid points that received too few observations to reduce system noise were removed. Evaluation of the actual vertical accuracy of the 
lidar could not be performed against ground-based surveying because the lidar flight path did not overlap the ground base station. Since no ground surveys were conducted concurrent with the September 17, 2008, lidar survey, a relative offset between the 2005 and 2008 data was determined. Lidar data were selected from a number of small areas containing fixed, flat features, such as roads, parking lots, and large buildings (fig. 6). For this intercomparison, a section of the city of Galveston was used. Grid cells were then selected based on their spatial error (normalized sampling error less than 25 percent and residual error less than $20 \mathrm{~cm}$ ) to eliminate cells with a small number of observations or high noise due to system behavior, or vegetation, or other sources of clutter. The grid cells that were selected were used to determine the relative offset of $+32(+/-0.001) \mathrm{cm}$ (fig. 7), indicating that the 2008 survey was biased high compared to the 2005 survey. This bias may be due to navigation errors in either or both of the surveys used in the comparison. Since the bias is within the vertical-error limits of the lidar surveys $(+/-20 \mathrm{~cm})$, the bias has not been removed from either dataset. The presence of a bias is important because it increases the uncertainty of the measures of coastal change presented in Section 4.2 .

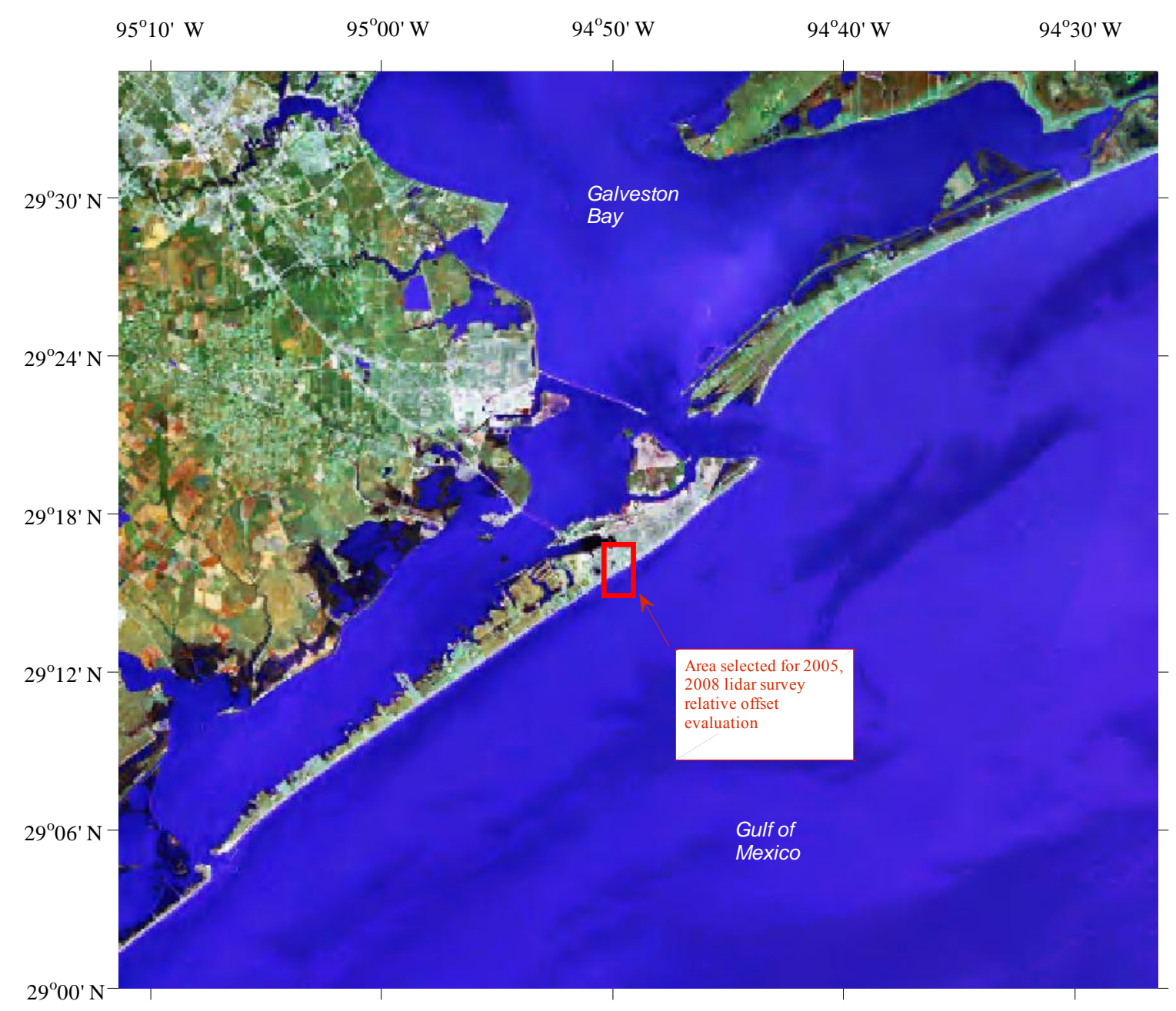

Figure 6. Map of Galveston Island. Red square shows location of the area selected for evaluating the relative offset between 2005 and 2008 lidar surveys. 


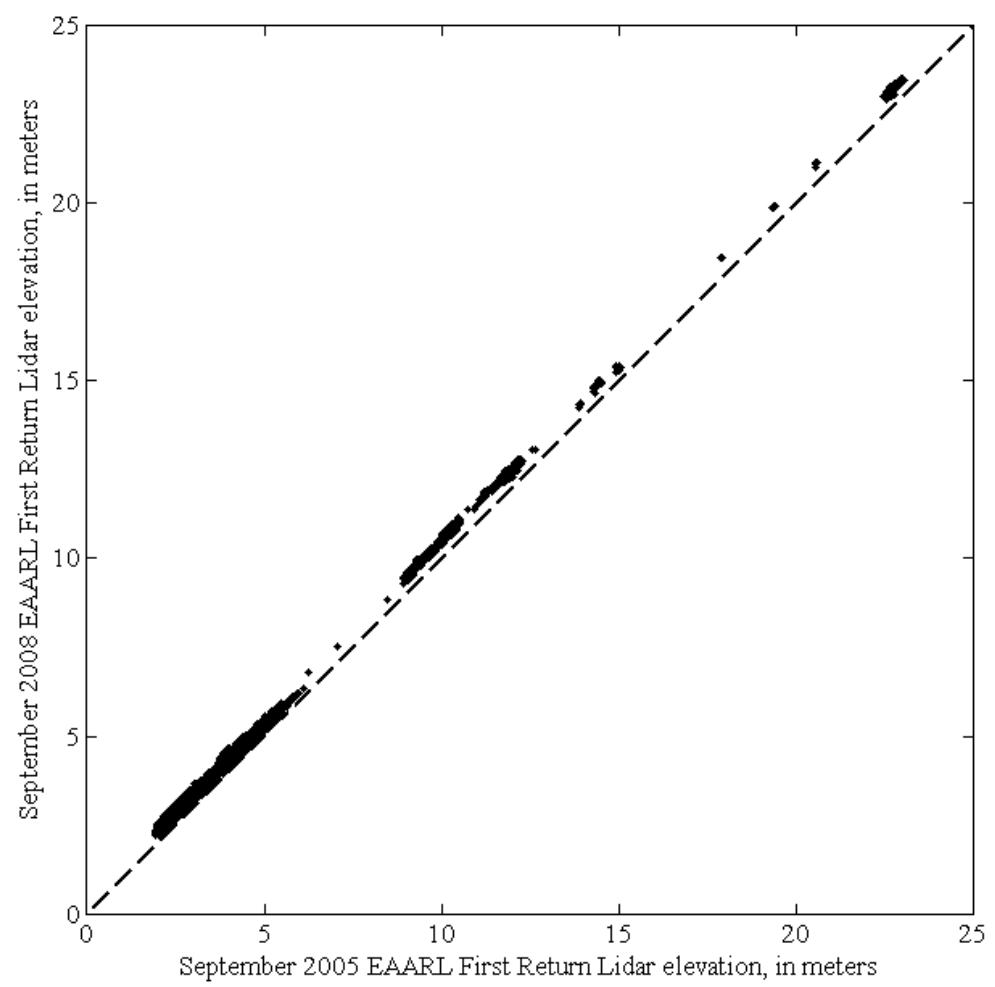

Figure 7. Relative offset between 2005 and 2008 Experimental Advanced Airborne Research Lidar first-return lidar.

\section{Coastal-Change Analysis}

The pre- and post-storm photography and the pre- and post-storm lidar topography were compared to describe and quantify the spatial extent, nature, and magnitude of coastal changes. The photography was used to identify examples of coastal changes that span the range of responses to the hurricane conditions. The lidar topography quantifies these changes. The quantitative analyses include estimates of changes in dune height, shoreline position, and sediment volume.

\subsection{Photo Comparison Analysis}

\subsubsection{Surfside Beach to San Luis Pass, Texas}

On the sandy beaches west of Galveston Island (fig. 8, locations 1 and 2), peak dune elevations before the storm ranged from 2 to $4 \mathrm{~m}$. The coastal change along this largely undeveloped stretch of beach was less severe than the change observed on Galveston Island and Bolivar Peninsula. Large waves and surge eroded the beach, causing shoreline retreat and scarping of the dune face (figs. 9 and $10)$. 


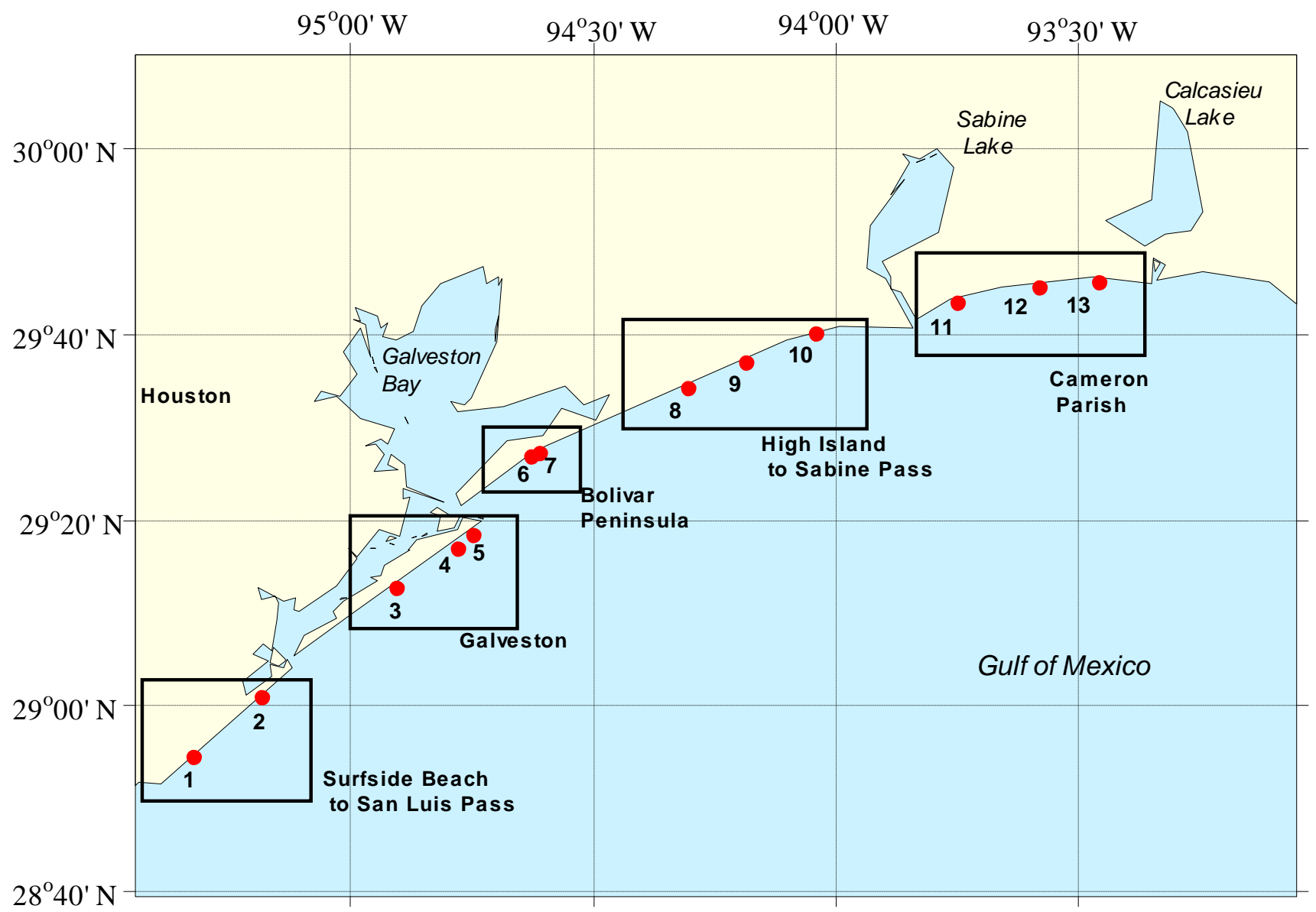

Figure 8. Location index for photo pairs (Figures 9-21) from Surfside Beach, Texas to Cameron Parish, Louisiana. 

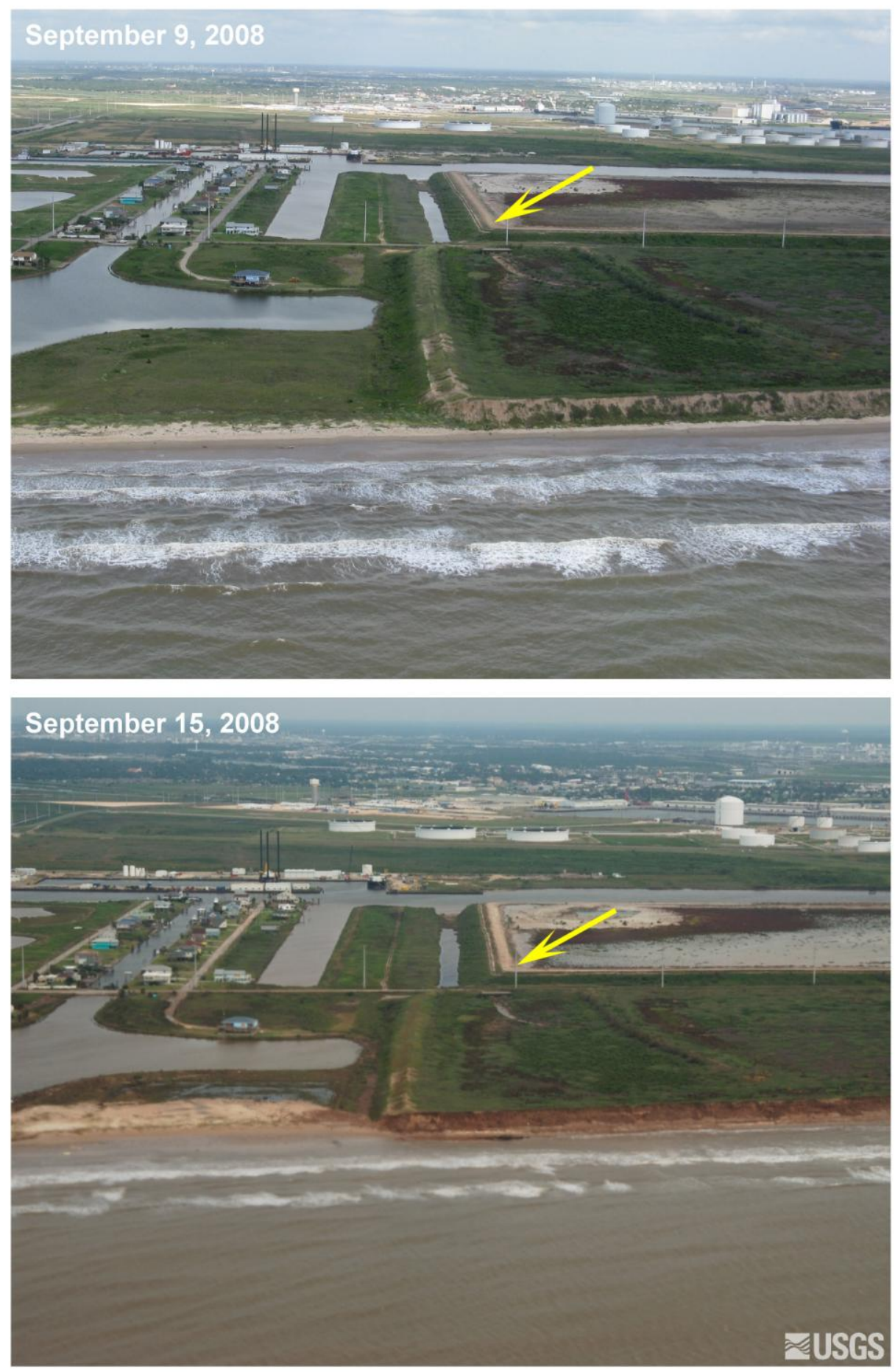

Figure 9. Oblique aerial photography from Quintana, Texas (Location 1, Figure 8) on September 9, 2008 (top) and September 15, 2008, two days after landfall of Hurricane lke (bottom). Yellow arrows mark features visible in each image. At this location well west of Ike's landfall location, there is evidence of erosion of the seaward leg of the rectangular berm. The steep scarp is typical of erosion due to wave collision against the berm slope. Erosion and overwash can be seen on the lower dune to the west (left) of the larger berm. 

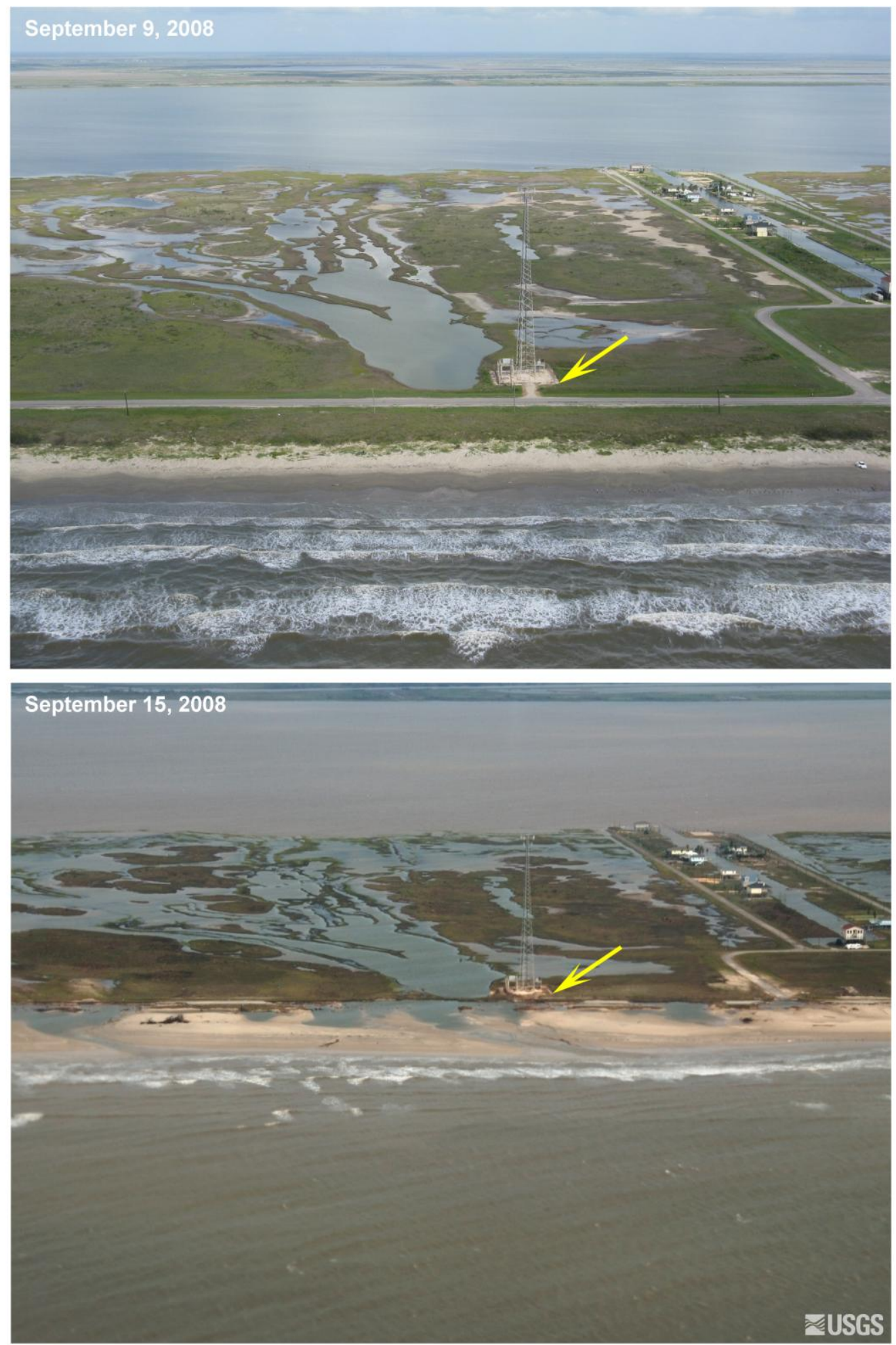

Figure 10. Oblique aerial photography from Christmas Bay, Texas (Location 2, Figure 8), on September 9, 2008 (top), and September 15, 2008, two days after landfall of Hurricane lke (bottom). Yellow arrows mark features visible in each image. Here, severe beach and dune erosion occurred, and overwash or inundation deposited sand behind remnants of the dune and onto the road. 


\subsubsection{Galveston, Texas}

Most of Galveston Island was west of Hurricane Ike landfall (fig. 8, locations 3-5) and was not exposed to the extreme winds of the right eyewall that devastated the Bolivar Peninsula. On the sandy beaches west of the Galveston seawall, peak dune elevations before the storm were 2 to $4 \mathrm{~m}$, roughly half of the elevation of the seawall. The coastal change along this stretch of Galveston Island was considerably more than on the seawalled section nearby, but less than the change observed on the Bolivar Peninsula. At landfall, while the Bolivar Peninsula was being pummeled with extreme onshore winds, much of Galveston Island experienced offshore winds, reducing both surge and, to some extent, wave heights. However, impacts were not absent. Waves, aided by high surge, eroded the beach, moving the shoreline landward of some houses west of the seawall (fig. 11).

The city of Galveston was protected from storm surge and wave attack by a 5- to 6-m high, 16$\mathrm{km}$-long seawall. Erosion was restricted to the beach in front of the seawall (fig. 12). Here, most of the severe impacts to buildings were confined to those that were built on piers that extended seaward of the seawall. A small section of the eastern end of the island was not protected by the seawall. This area was on the right-hand side of the hurricane track and likely experienced the strongest winds, and the highest surge and waves, leading to beach and dune erosion (fig. 13). 

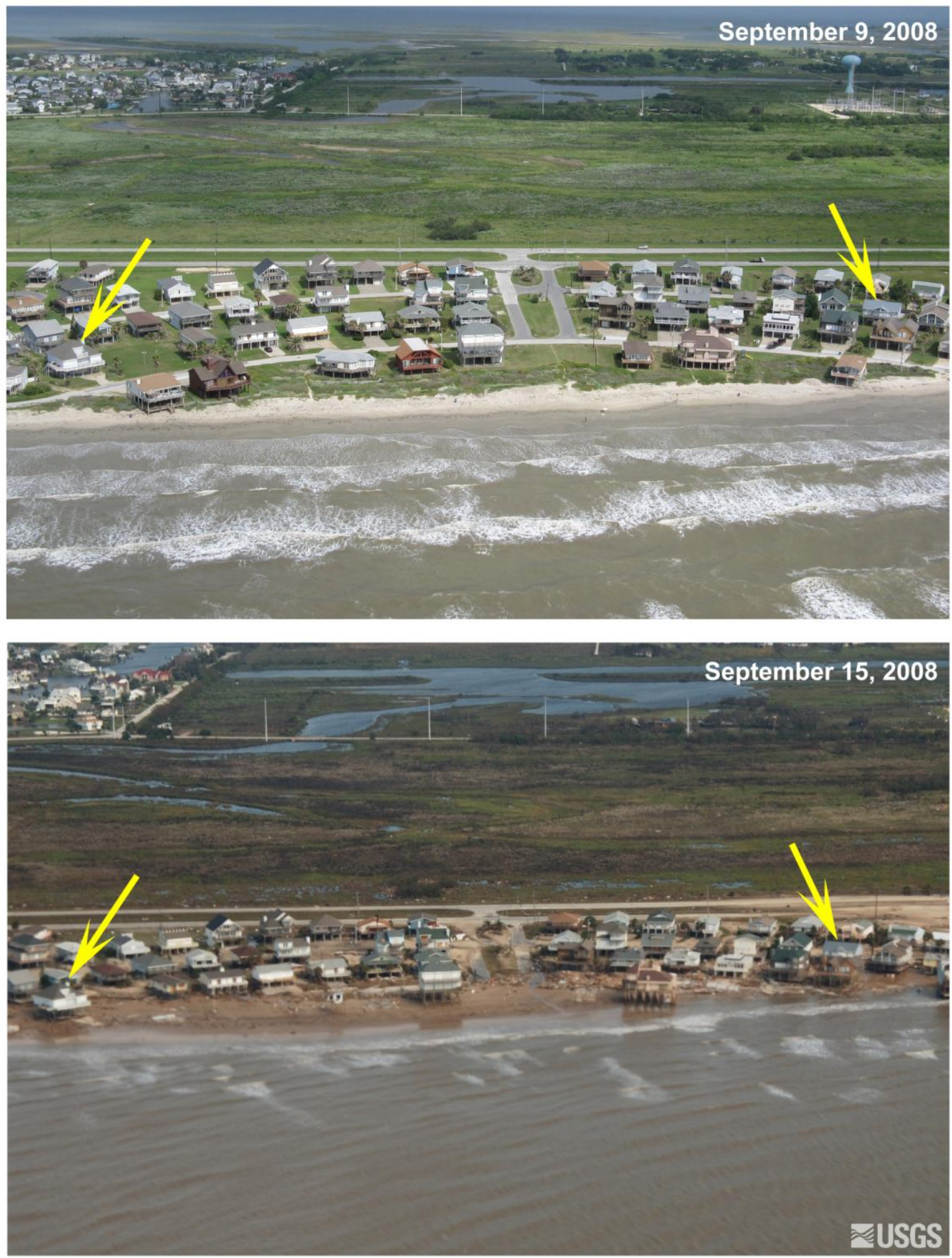

Figure 11. Oblique aerial photography of Galveston, Texas (Location 3, Figure 8), on September 9, 2008 (top), and September 15, 2008, two days after landfall of Hurricane lke (bottom). Yellow arrows mark features visible in each image. Evidence of inundation here includes eroded beach face, sand deposited inland of the shoreline, and distressed vegetation. However, the coastal-change impacts were less severe here than on the Bolivar Peninsula, located northeast of landfall. 

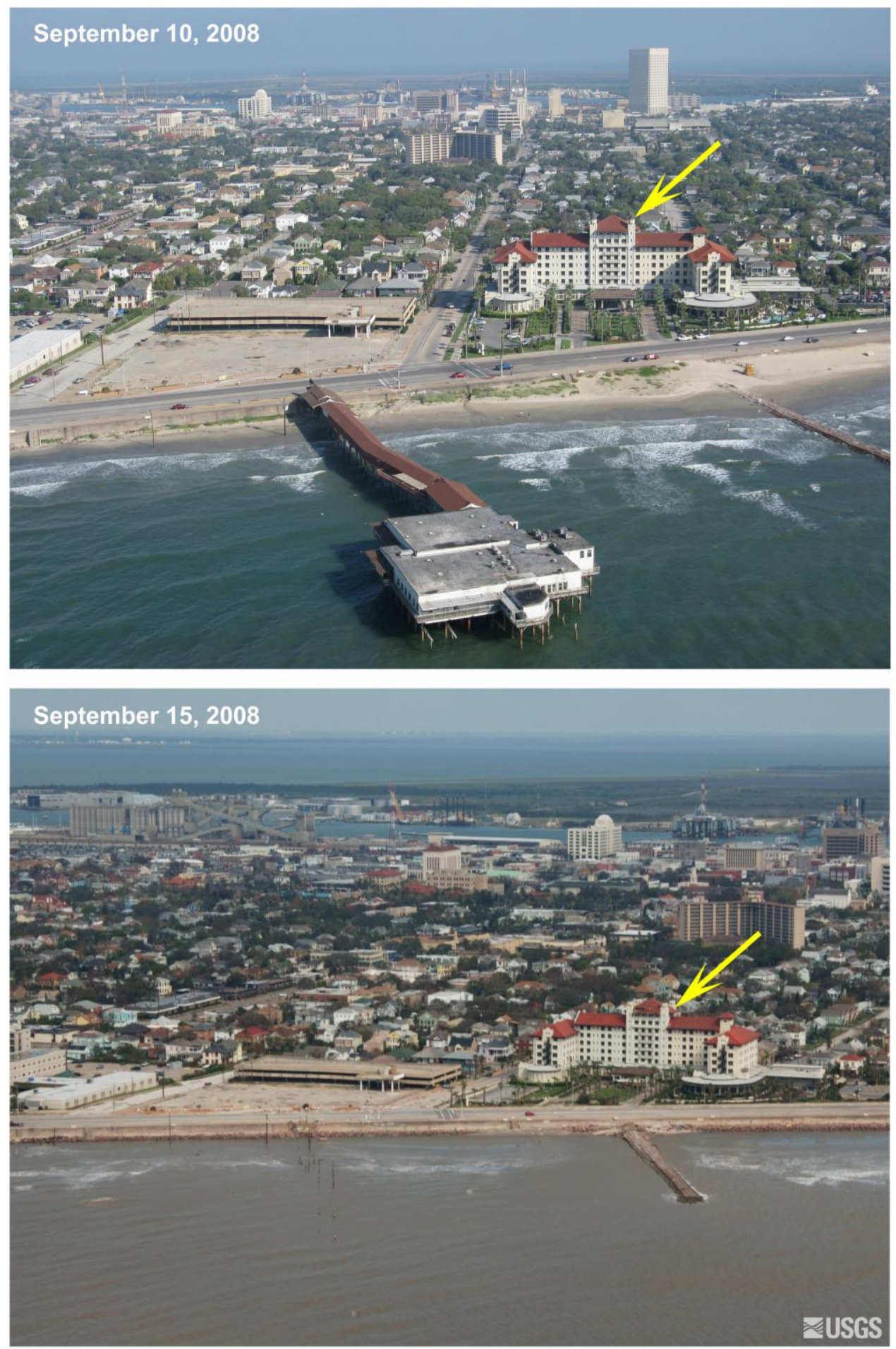

Figure 12. Oblique aerial photography of Galveston, Texas (Location 4, Figure 8), on September 9, 2008 (top) and September 15, 2008, two days after landfall of Hurricane lke (bottom). Yellow arrows mark features visible in each image. Hurricane-induced waves and surge destroyed a pier and eroded adjacent beaches. 

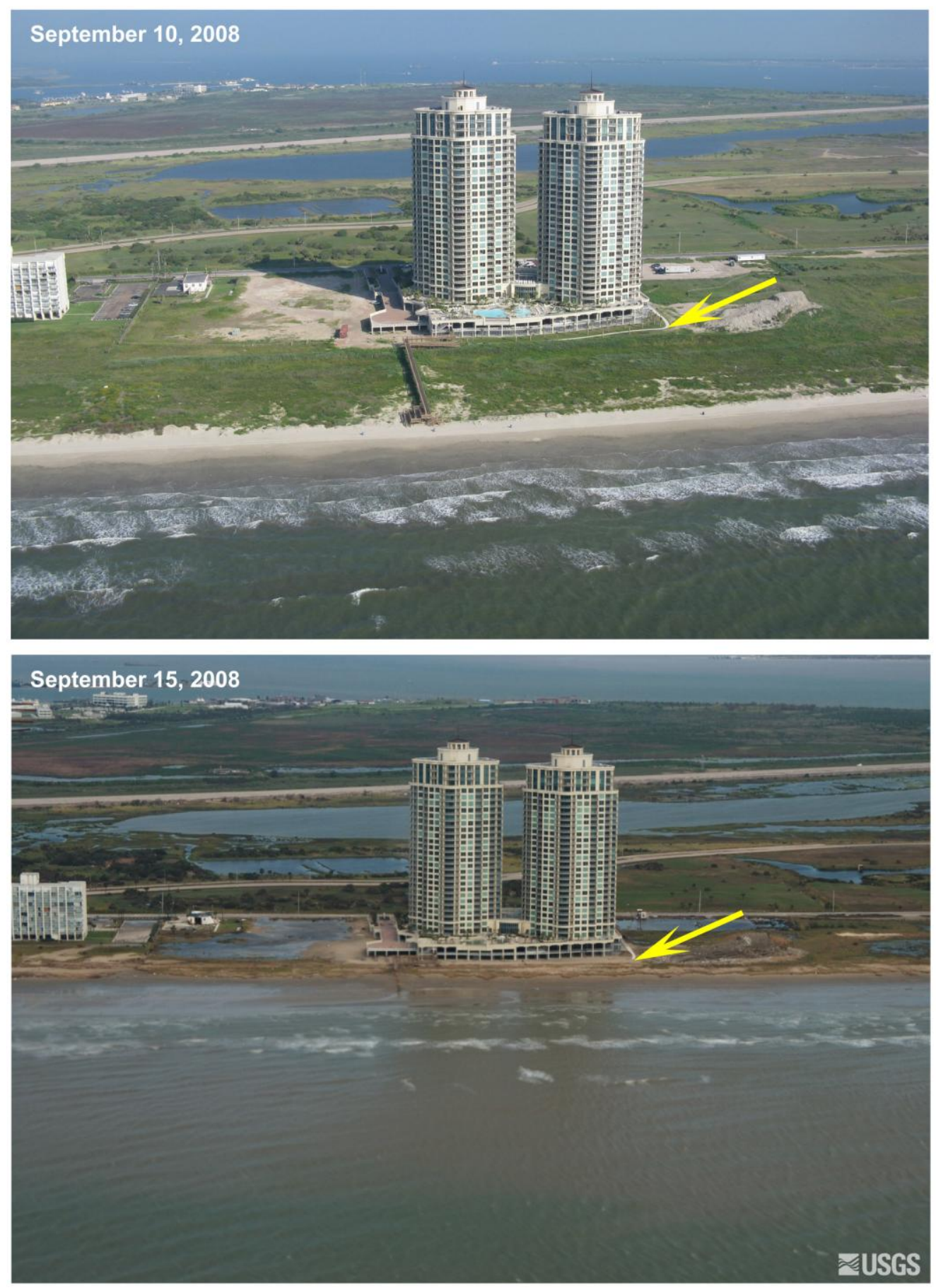

Figure 13. Oblique aerial photography of Galveston, Texas (Location 5, Figure 8), on September 9, 2008 (top) and September 15, 2008, two days after landfall of Hurricane lke (bottom). Yellow arrows mark features visible in each image. Hurricane-induced waves and surge destroyed a small walkway. Coastal-change impacts include beach and dune erosion, and the removal of considerable dune vegetation. This location is on the right-hand side of the hurricane track and likely experienced the strongest winds, highest surge, and waves. 


\subsubsection{Bolivar Peninsula}

Hurricane Ike made landfall at the mouth of Galveston Bay, thus exposing the coast lying east of landfall to the right-front quadrant of the storm, the location of the strongest winds. The storm surge, onshore-directed winds, and waves all focused their greatest energy in this area. The combination of low dunes and high-surge levels on the Bolivar Peninsula (fig. 8, locations 6 and 7) made those beaches vulnerable to inundation and large-scale coastal changes during landfall. Entire neighborhoods were destroyed by battering waves riding on top of a 5-m storm surge. Low sand dunes (about 2 m elevation) protecting beach-front neighborhoods were flattened by erosion, and sand from the beach and dunes was transported landward and ultimately deposited across the width of several blocks (figs. 14 and 15). At the narrowest part of the Peninsula near Gilchrist, Texas, the sand and debris were swept into Galveston Bay. 

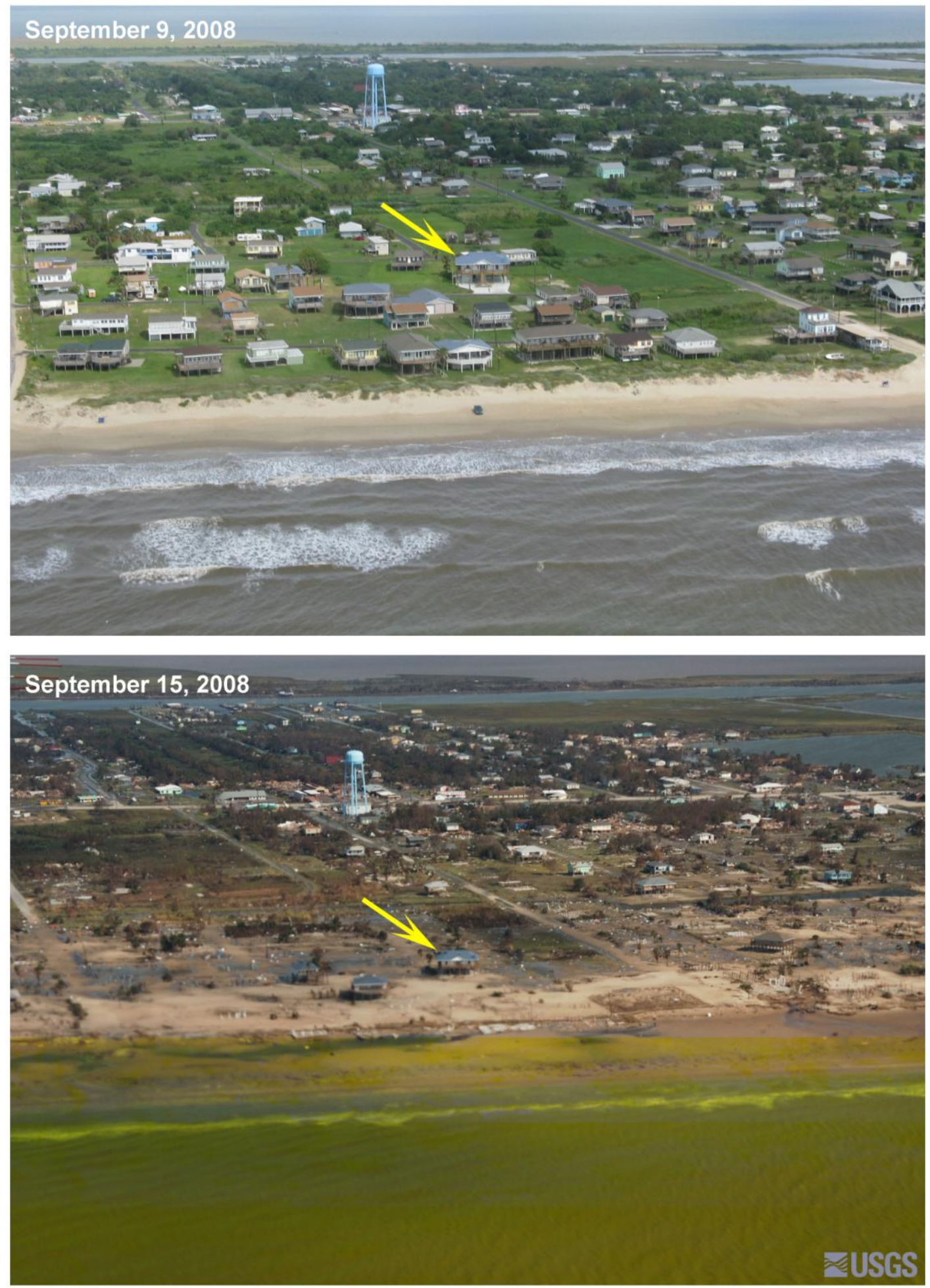

Figure 14. Oblique aerial photography of Bolivar Peninsula, Texas (Location 6, Figure 8), on September 9, 2008 (top) and September 15, 2008, two days after landfall of Hurricane lke (bottom). Yellow arrows mark features visible in each image. In addition to loss of houses, the evidence of inundation here includes eroded dune face and sand deposited well inland of the shoreline. 

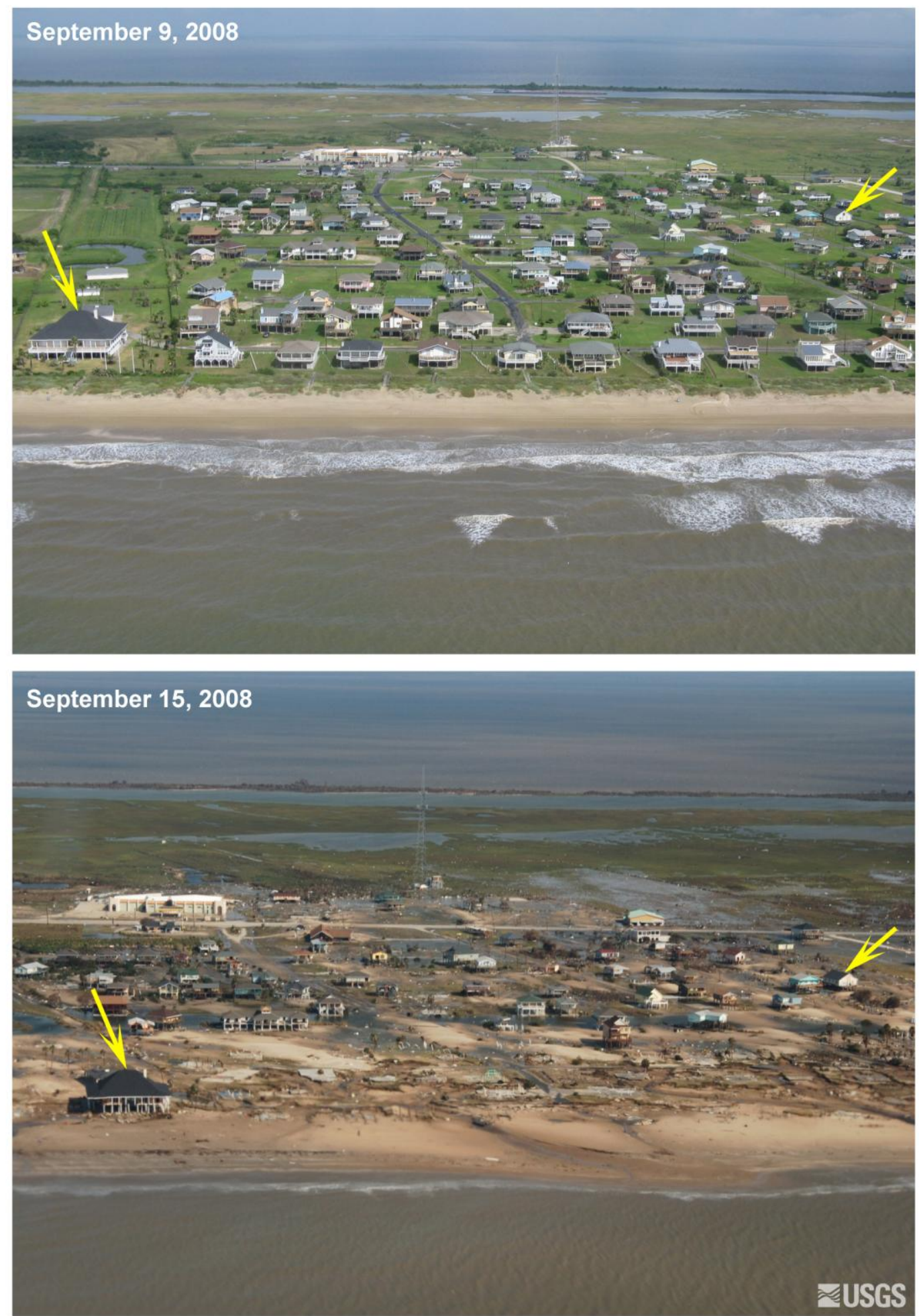

Figure 15. Oblique aerial photography of Bolivar Peninsula, Texas (Location 7, Figure 8), on September 9, 2008 (top), and September 15, 2008, two days after landfall of Hurricane lke (bottom). Yellow arrows mark features visible in each image. In addition to the loss of houses, the evidence of inundation here includes eroded dune face and sand deposited well inland of the shoreline. 


\subsubsection{High Island to Sabine Pass, Texas}

Farther east across the upper Texas coast (fig. 8, locations 8-10), the pre-storm morphology was different and so were the impacts. Before the storm, dune elevations (or berms in the absence of dunes) were extremely low, ranging from only 1 to $2 \mathrm{~m}$ high. Landward of mainland beaches were low-lying marshlands. The storm surge of 3 to $4 \mathrm{~m}$ overtopped the beach systems and, in places, inundated the marshes tens of kilometers landward from the shoreline. Two days after the storm, floodwaters were still present, held in place by what remained of the beaches that acted like levees containing the water (figs. 16 and 17). The beach crests rose above the water and resembled barrier islands, whereas they were actually mainland beaches. Breaches were cut through these 'barriers' and water flowed seaward, slowly draining the huge, shallow lakes. During this process, eroded sand was transported seaward into the Gulf of Mexico (fig. 18). 

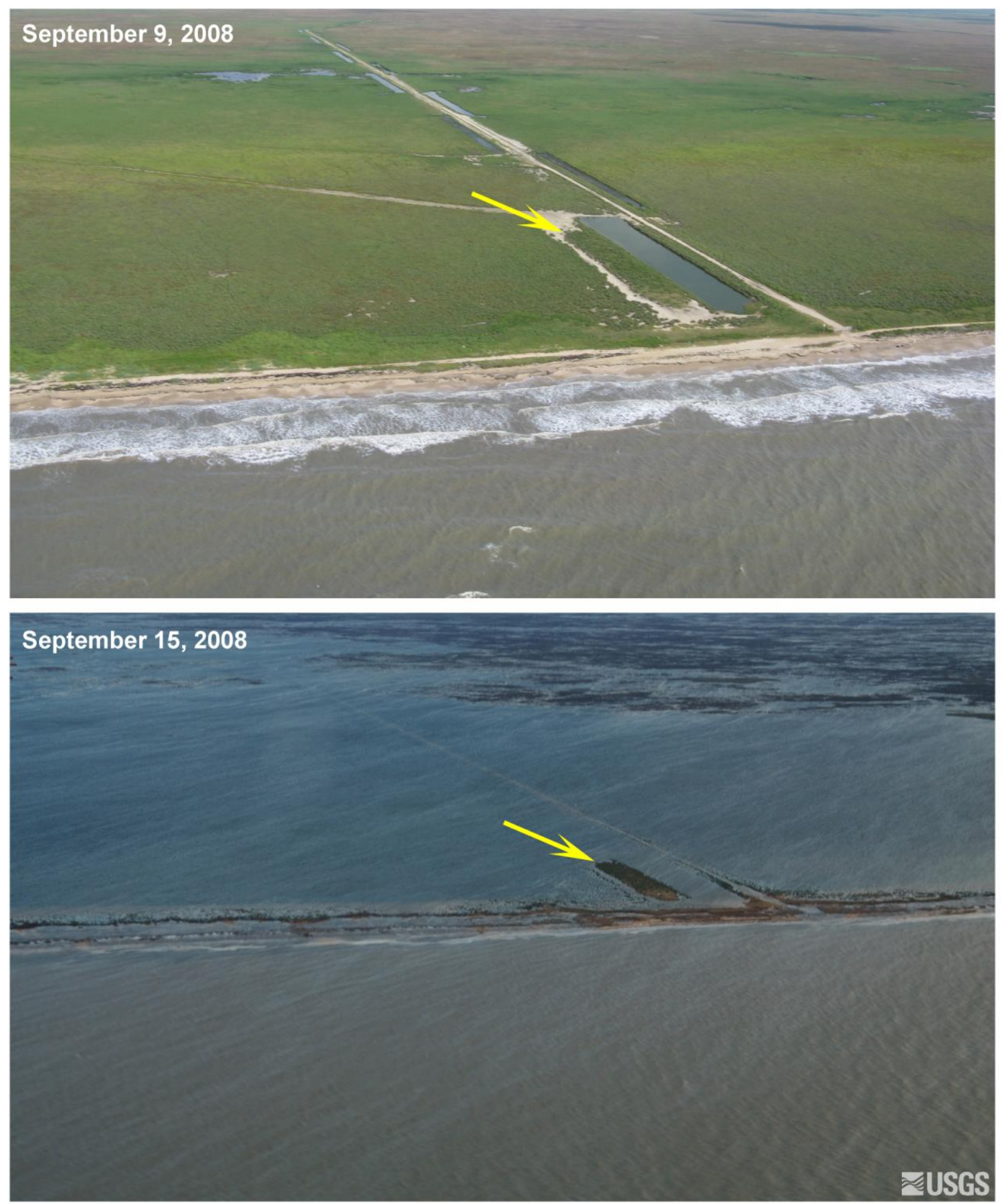

Figure 16. Oblique aerial photography near McFaddin Wildlife Refuge, Texas (Location 8, Figure 8), on September 9, 2008 (top) and September 15, 2008, two days after landfall of Hurricane lke (bottom). Yellow arrows mark features visible in each image. Widespread inundation and persistent flooding are obvious but the extent of coastal change is difficult to assess. 


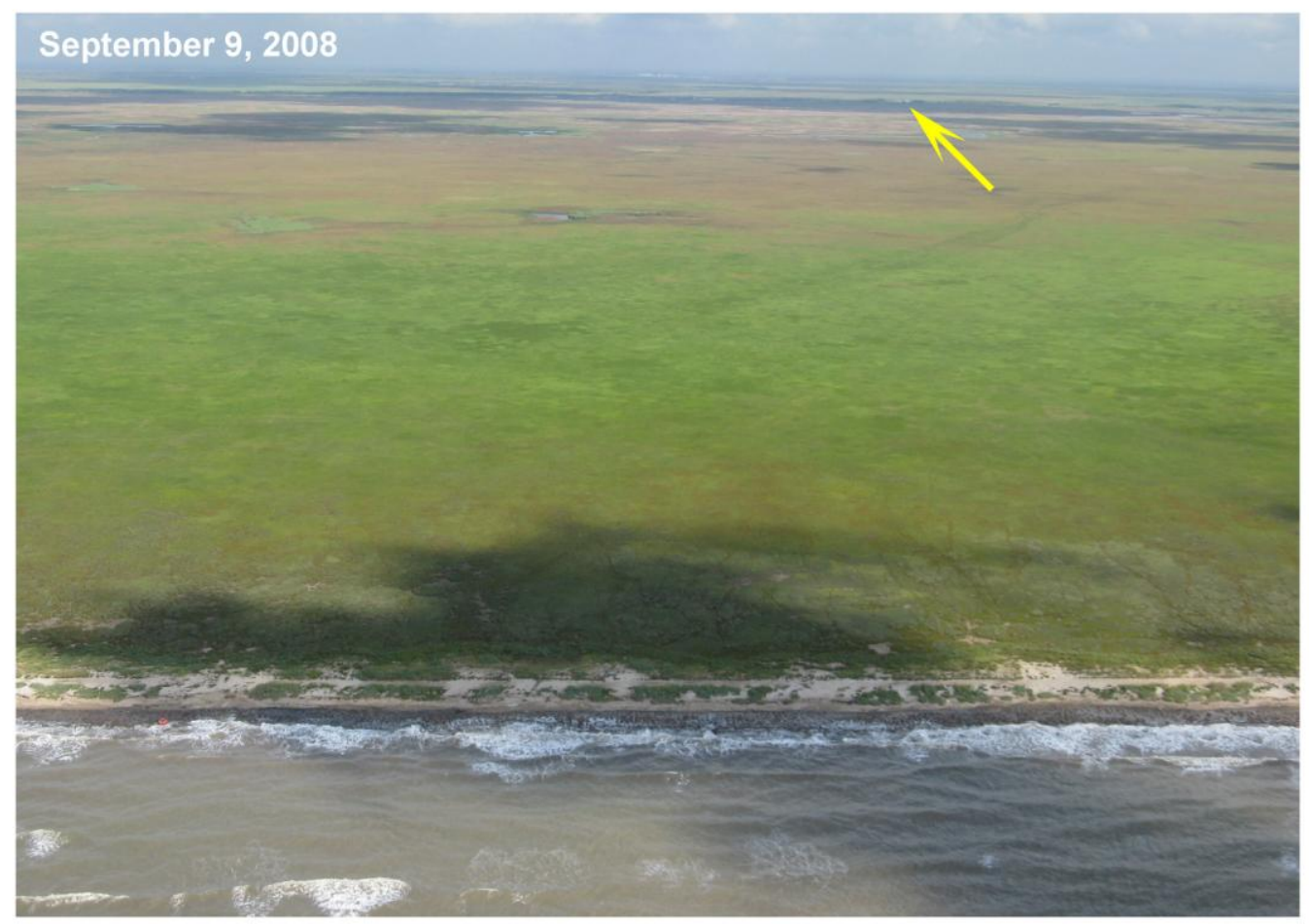

\footnotetext{
September 15, 2008
}

₹USGS

Figure 17. Oblique aerial photography near McFaddin Wildlife Refuge, Texas (Location 9, Figure 8), on September 9, 2008 (top) and September 15, 2008, two days after landfall of Hurricane lke (bottom). Yellow arrows mark features visible in each image. Again, widespread inundation and persistent flooding are obvious. The white foam at the bottom of the post-storm photo is due to the return flow cascading over the berm as the area drains into the Gulf of Mexico. 


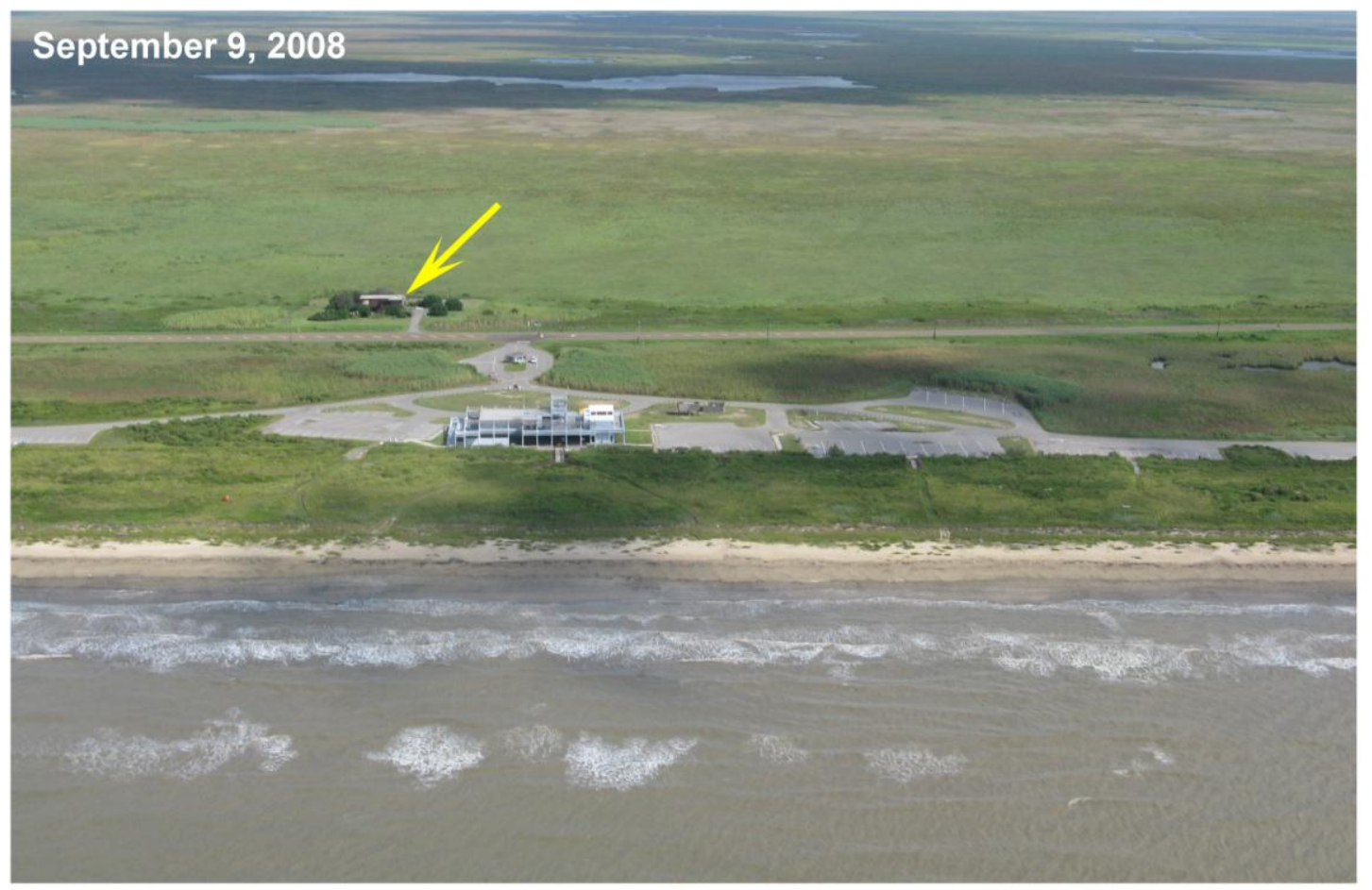

September 15, 2008

₹USGS

Figure 18. Oblique aerial photography near McFaddin Wildlife Refuge, Texas (Location 10, Figure 8), on September 9, 2008 (top) and September 15, 2008, two days after landfall of Hurricane lke (bottom). Yellow arrows mark features visible in each image. Evidence of widespread inundation is apparent. The flooded area continues to drain through a channel that cuts through the roadway. The dunes have been eroded and dissected. Backflow through this area transported sediment offshore. 


\subsubsection{Cameron Parish, Western Louisiana}

The morphology of the western Louisiana coast (fig. 8, locations 11-13) is similar to that of the Texas coastline north of the Bolivar Peninsula. Before the storm, dune elevations (or berms in the absence of dunes) were low, ranging from only 1 to $2 \mathrm{~m}$ high. Landward of the beaches were low-lying marshlands. The storm surge of 1 to $3 \mathrm{~m}$ overtopped the beach systems in many areas, and waves (figs. 19 and 20) eroded the shoreline landward. The town of Holly Beach, Louisiana, which was completely destroyed by Hurricane Rita in 2005, was once again flooded by Hurricane Ike (fig. 21). 

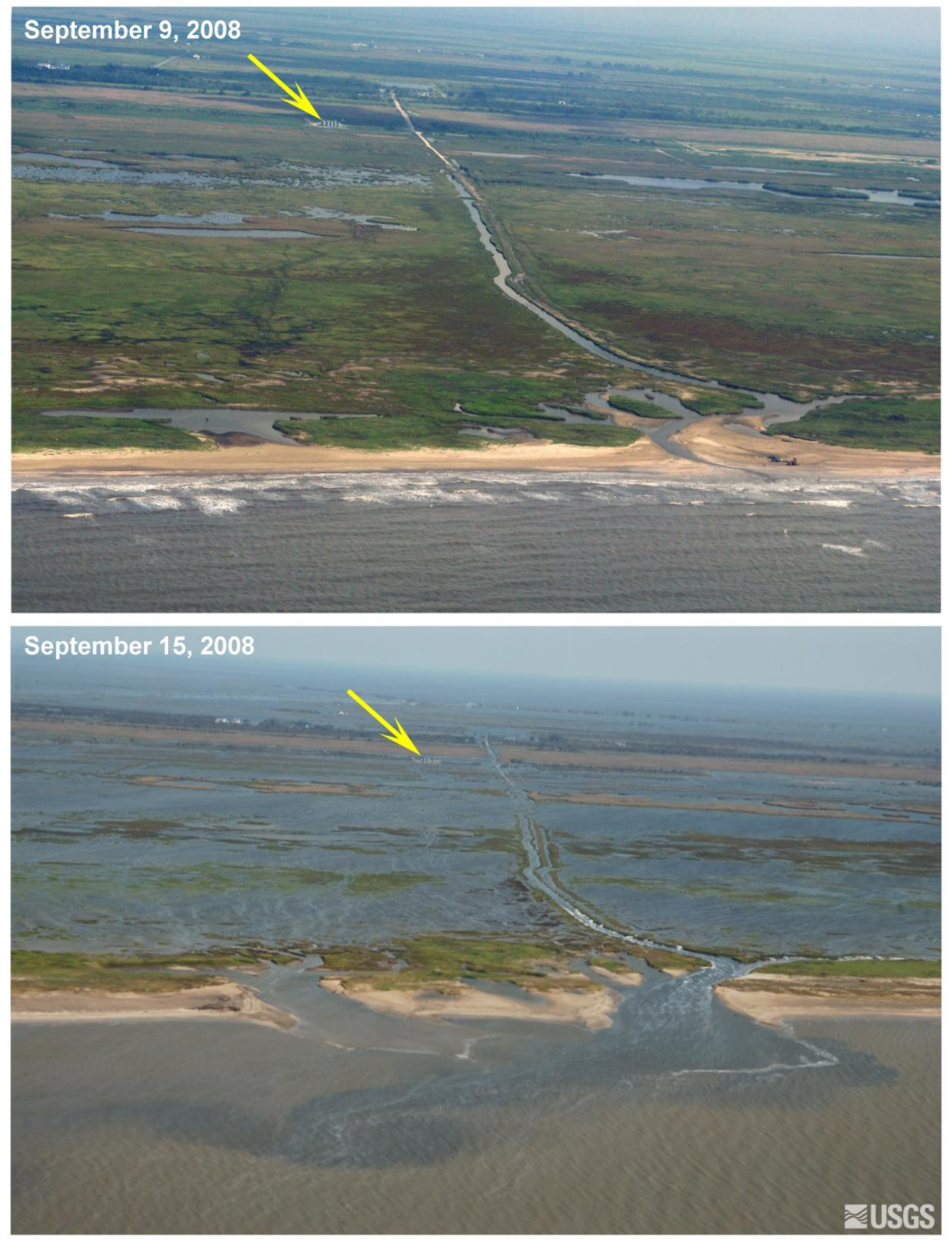

Figure 19. Oblique aerial photography from Cameron Parish, Louisiana (Location 11, Figure 8), on September 9, 2008 (top) and September 15, 2008, two days after landfall of Hurricane lke (bottom). Yellow arrows mark features visible in each image. Widespread inundation and persistent flooding are obvious. Coastal change includes both beach erosion and erosion of channels where water continues to flow seaward to the Gulf of Mexico. 


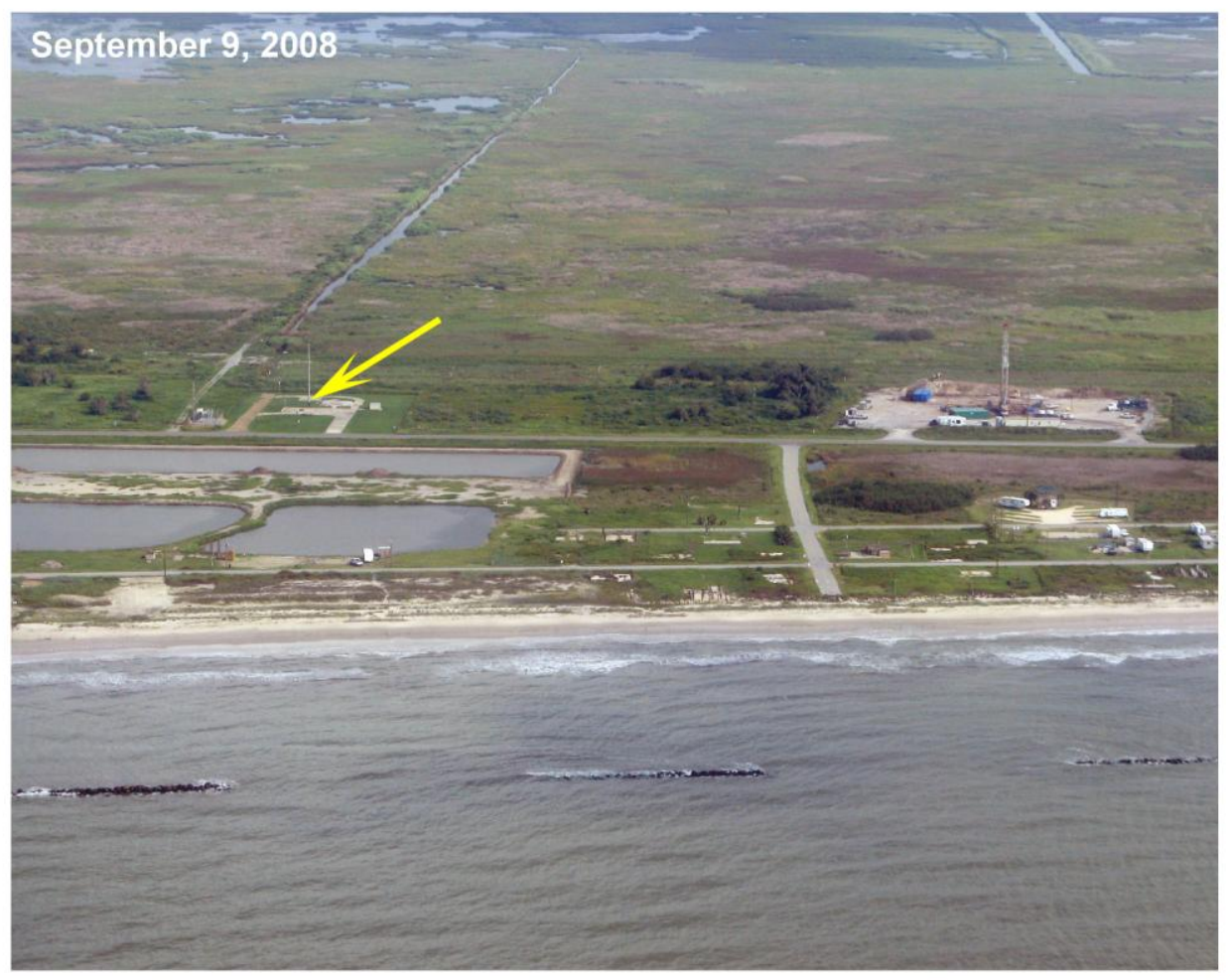

September 15, 2008

₹USGS

Figure 20. Oblique aerial photography from Peveto Beach, Louisiana (Location 12, Figure 8), on September 9 , 2008 (top) and September 15, 2008, two days after landfall of Hurricane lke (bottom). Yellow arrows mark features visible in each image. Evidence of widespread inundation includes erosion of the berm and channels that drained the flooded area. 

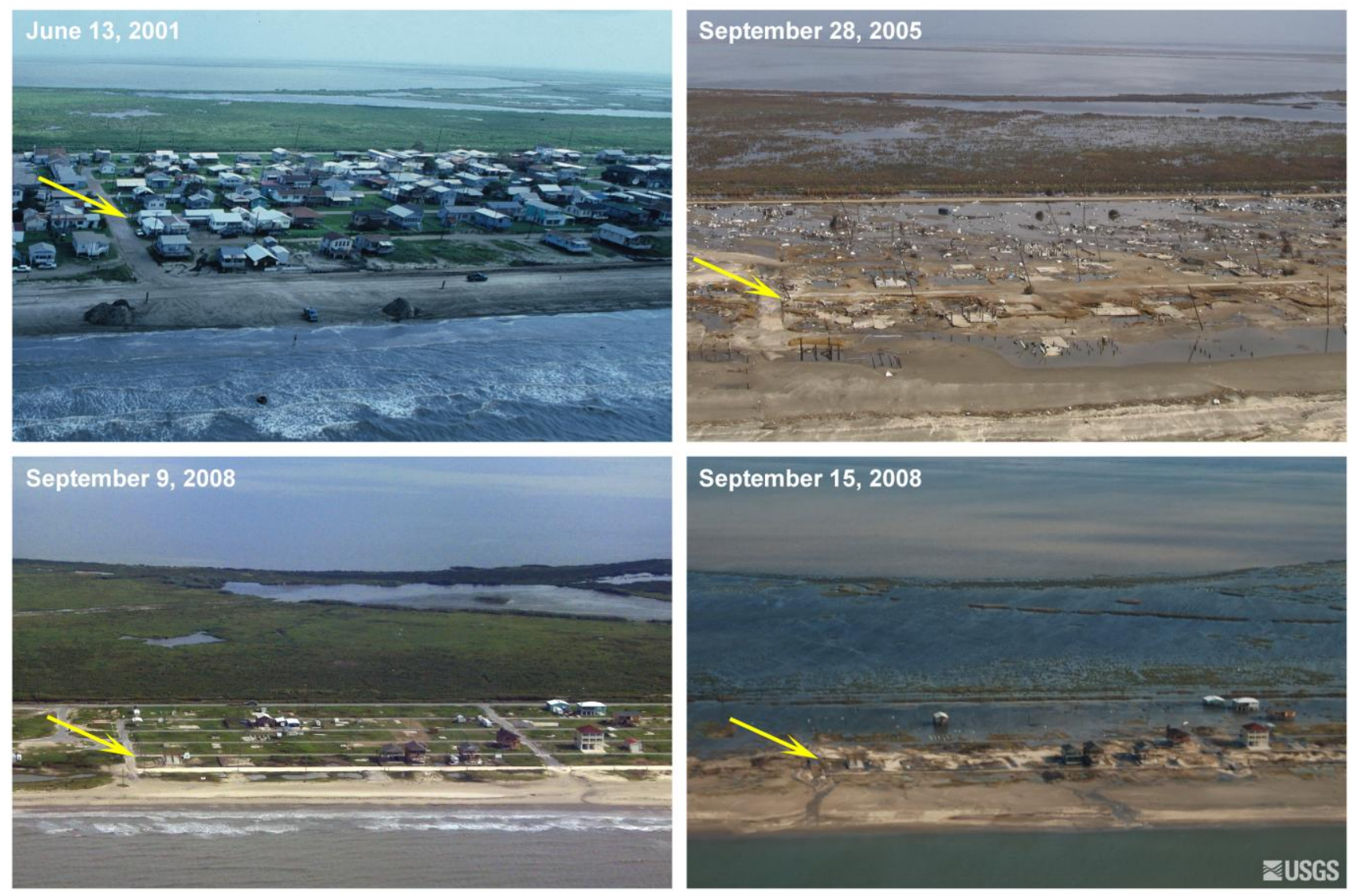

Figure 21. Oblique aerial photography from Holly Beach, Louisiana (Location 13, Figure 8), from 2001-2008.

Yellow arrows mark features visible in each image. The first photo shows this area prior to landfall of Hurricane Rita on September 24, 2005. Immediately after Rita's landfall, the September 28, 2005, photo shows destruction of houses. Prior to Ike's landfall, on September 9, 2008 there is little evidence of a dune or berm on this beach. Several houses and smaller structures have been rebuilt. On September 15, 2008, two days after landfall of Hurricane lke, the beach is eroded and there is evidence of overwash and persistent flooding.

\subsection{Quantitative Topographic-Change Analysis}

Last-return lidar data were analyzed to compare morphologic changes due to Hurricane Ike. The morphologic analysis was optimized for identifying shorelines and dune height. The analysis required interpolation to a gridded domain that was rotated parallel to the shoreline and had a resolution of $10 \mathrm{~m}$ in the longshore direction and $2.5 \mathrm{~m}$ in the cross-shore direction. The interpolation method applies spatial filtering with a Hanning window that is twice as wide as the grid resolution (Plant and others, 2002). Grids of pre- and post-storm lidar topography can be differenced over the entire overlapping survey area to compute elevation or volume changes over various distances and to give a quick visual of coastal change. For the town of Crystal Beach, Texas, on the Bolivar Peninsula, difference grids reveal loss of homes, erosion of the shoreline, and reduction of dune elevations (figs. 22-24). Overwash deposits (fig. 24) can be seen several hundred meters from the shoreline. 


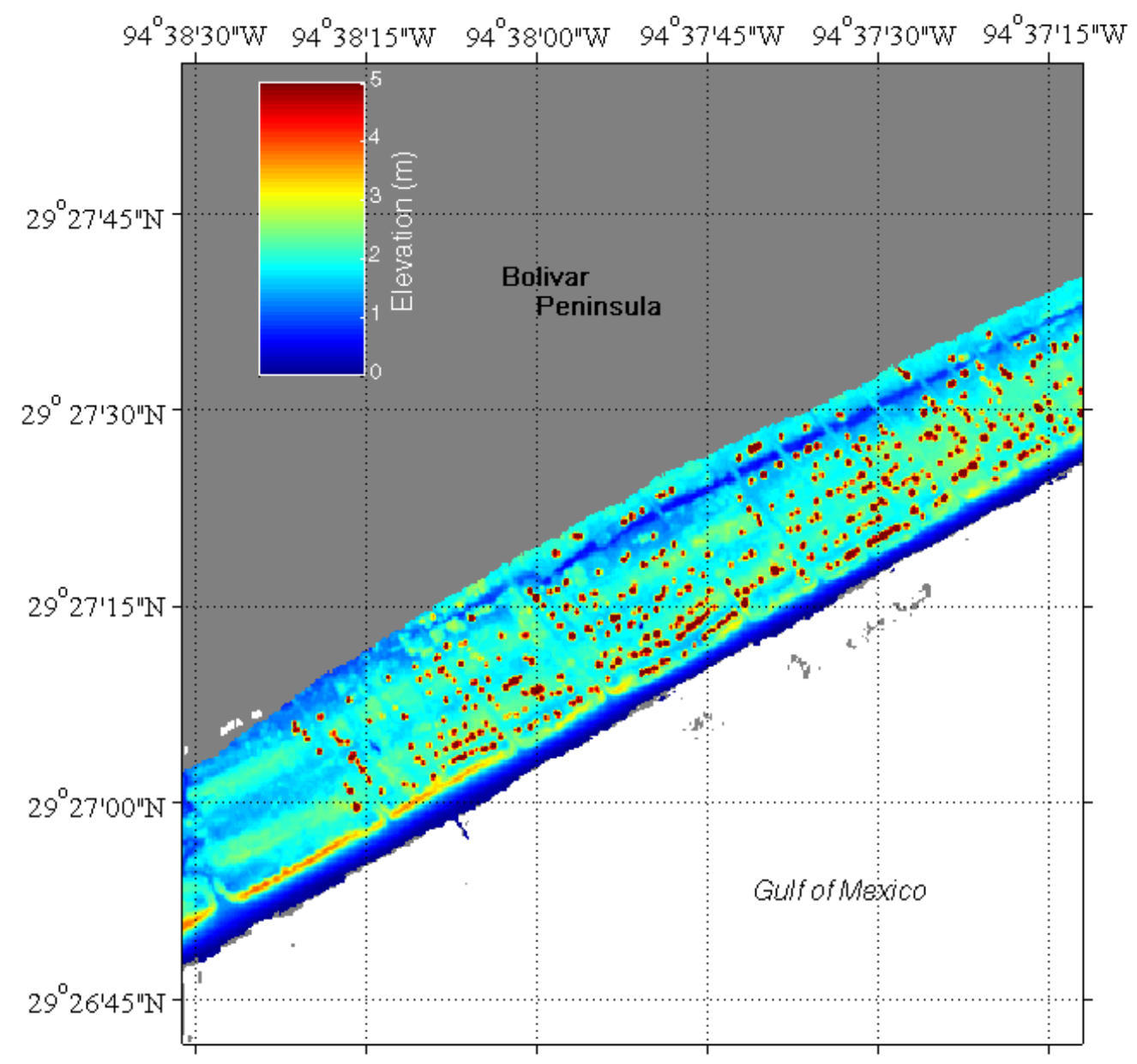

Figure 22. September 2005 Experimental Advanced Airborne Research Lidar first-return lidar digital elevation model of Crystal Beach, Texas. 


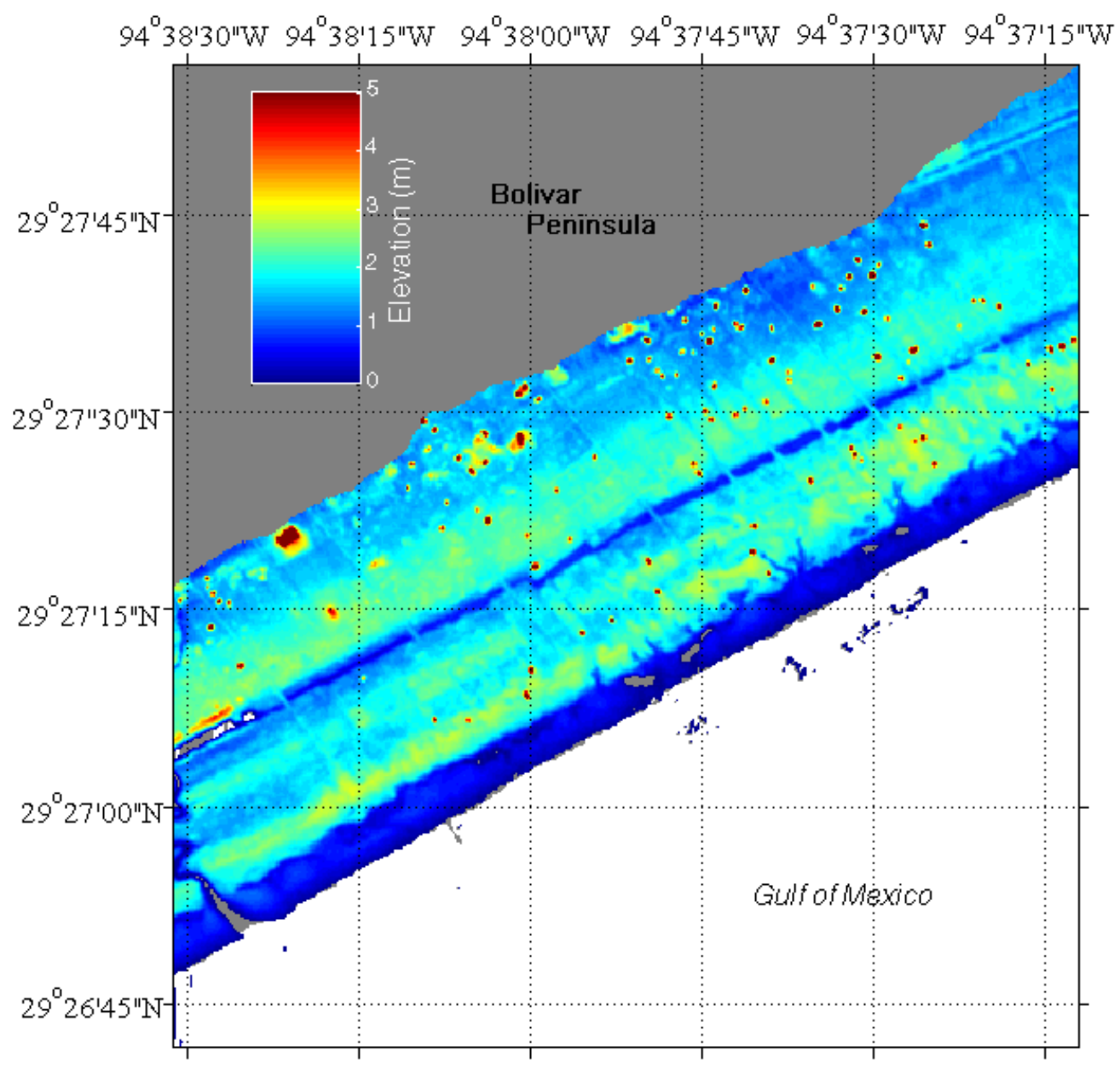

Figure 23. September 2008 Experimental Advanced Airborne Research Lidar first-return lidar digital elevation model of Crystal Beach, Texas. 


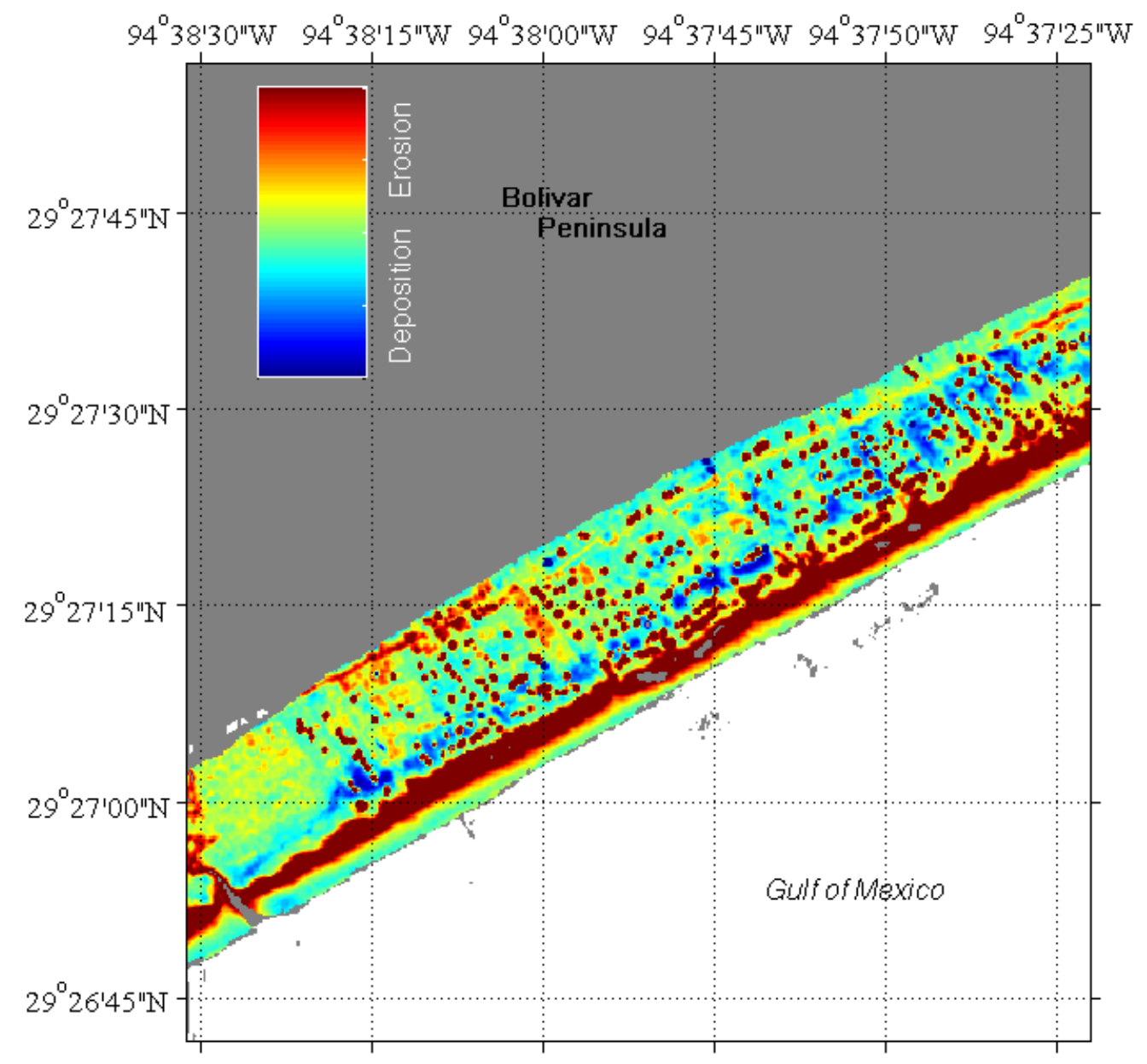

Figure 24. Coastal Change at Crystal Beach, Texas, due to Hurricane Ike. The coastal change between the two dates is determined from the difference between the two datasets. For the coastal-change figure, red indicates at least $1 \mathrm{~m}$ of erosion and blue indicates at least $1 \mathrm{~m}$ of deposition. The spatial coverage of the two data sets differs and the 2008 mission had more extensive coverage than the 2005 mission in this area.

\subsubsection{Dune Elevation Change}

Gridded lidar data were used to estimate changes in elevation and position of the frontal sand dune or berm system (Stockdon and others, in press). Dune or berm-elevation change is calculated as the difference between elevation of the pre-storm dune crest (September 2005) and the post-storm elevation (September 2008) (fig. 25A). The elevation change is estimated at the location of the prestorm dune crest.

Extreme elevation changes of about $3 \mathrm{~m}$ were observed near Crystal Beach, Texas, which is located on the Bolivar Peninsula and was in the right-front quadrant of the hurricane impact zone. Dune-height changes exceeding $1 \mathrm{~m}$ were observed more than $60 \mathrm{~km}$ to the right of the landfall position. 
Dune-height changes exceeding $1 \mathrm{~m}$ were observed as far as $40 \mathrm{~km}$ to the left of landfall. In Galveston, Texas, the seawall is considered to be the dune crest and the elevation change is roughly $30 \mathrm{~cm}$, consistent with the previously determined vertical offset.

\subsubsection{Shoreline Change}

From each row of the shore-parallel-oriented grids, the cross-shore position of the datum-based shoreline was extracted (Stockdon and others, 2002). The shoreline vertical datum was defined to be $0.37 \mathrm{~m}$ above mean sea level, based on NAVD88 vertical datum and GEOID96 model. These shoreline positions are compared to shorelines from the pre-storm survey, providing a quantitative description of shoreline change. Shoreline change is calculated as the difference between the pre-storm shoreline (September 2005) and the post-storm shoreline from the EAARL survey of September 17, 2008 (fig. 25B). Uncertainties in shoreline position vary due to data noise and beach slope, but typical errors in shoreline position are on the order of 1-2 m (Stockdon and others, 2002). Because the surveys span 3 years, the shoreline change can be both storm-induced short-term and background long-term change.

Shoreline erosion of $150 \mathrm{~m}$ was observed near Gilchrist, Texas. More than $50 \mathrm{~m}$ of shoreline erosion was experienced over a wide region from the seawall extending $15 \mathrm{~km}$ to the west. The area of positive shoreline change at the south end of Galveston Island is related to spit formation at San Luis Pass and may not be related to Hurricane Ike. The area of positive shoreline change $80 \mathrm{~km}$ to the right of landfall is due to the seaward transport of sediment as storm water drained from the marshes (fig. 18).

\subsubsection{Beach-Volume Change}

Volume-change calculations were performed by contouring the topography at a fixed vertical datum, which was set at mean high water from tidal records (Weber and others, 2005). The volume is calculated between the cross-shore location of the pre-storm dune base and the pre-storm shoreline. This eliminates complications from structures and vegetation, which generally are located landward of the dune base. Beach volume change was calculated as the difference between the September 2005 and September 2008 surveys (fig. 25C).

Volume losses typically follow the same pattern as the shoreline changes in the region to the west of Galveston. This implies that sediment lost due to erosion was not deposited farther landward. East of landfall, volume changes were highly variable. Some areas, such as the region between Crystal Beach and Gilchrist, Texas, experienced substantial volume loss. However, the town of Crystal Beach, Texas, experienced little net sediment loss. This is consistent with the appearance of overwash deposits that presumably contain the sediment that was eroded from the shoreline and dunes (fig. 24). The positive volume change near the San Luis Pass at the south end of Galveston Island is likely long-term sediment accumulation at the inlet. Volume change along the seawall of Galveston is positive due to the 30-cm relative offset. 

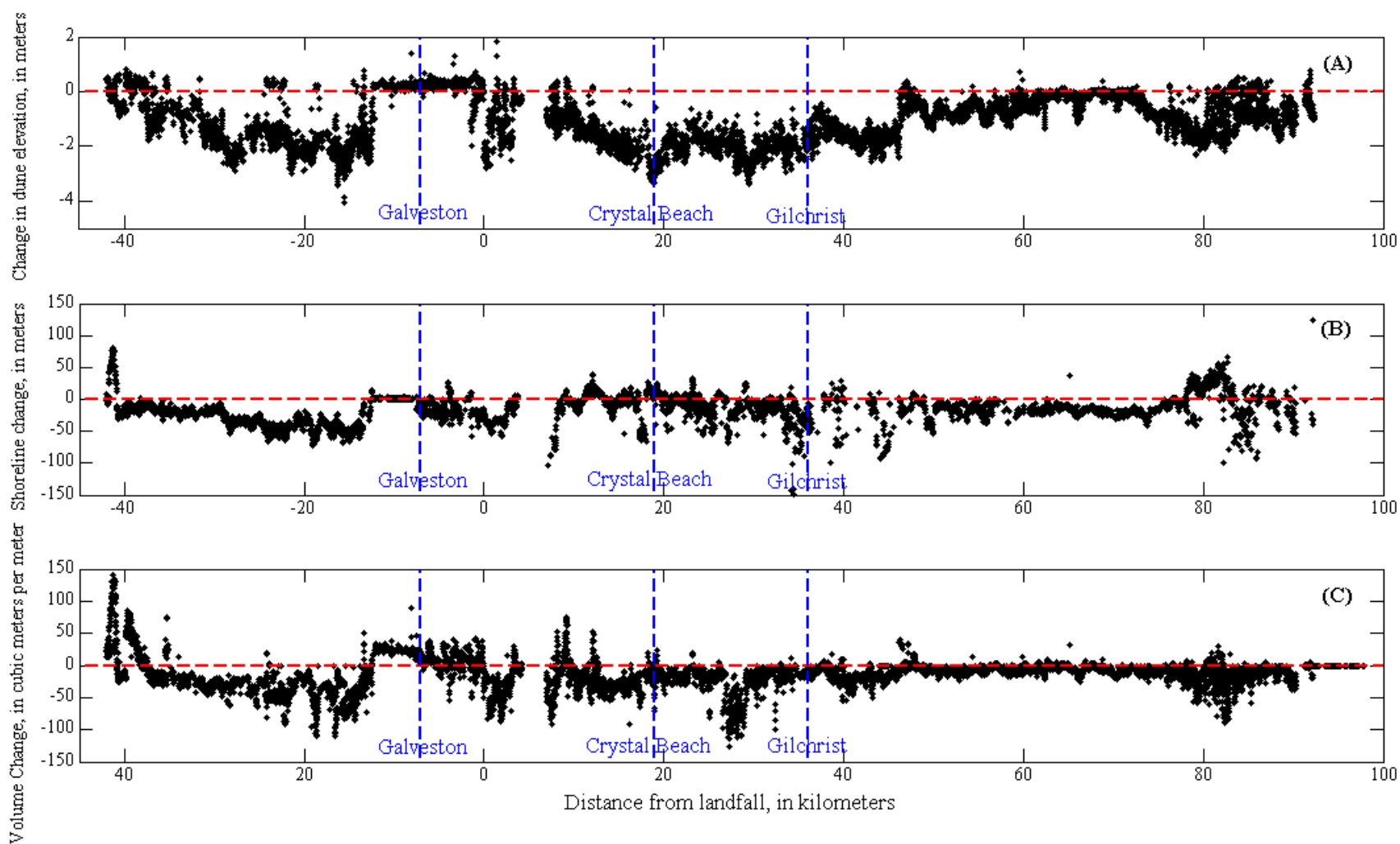

Figure 25. Hurricane lke $(A)$ dune-elevation change $(B)$ shoreline change $(C)$ and beach-volume change. Blue lines indicate the center of the towns of Galveston, Crystal Beach, and Gilchrist, Texas.

\section{Acknowledgments}

The USGS National Assessment of Coastal Change Hazards Project thanks the many scientists and support staff who invested long hours during the 2008 hurricane season. Specifically, we thank the EAARL research team (Wayne Wright and Richard Mitchell) and ground surveyor (B.J. Reynolds). Colleagues at the University of New Orleans conducted the pre-storm photography mission (Karen Westphal); colleagues in the St. Petersburg office helped with data collection (Dennis Krohn, Karen Morgan, and Kristy Guy), processing and analysis (Charlene Sullivan, Peter Howd, Mark Hansen, Dave Thompson, and Ann Marie Ascough), and web page development (Jolene Shirley). 


\section{References Cited}

Berg, R., 2009, Tropical cyclone report Hurricane Ike: National Oceanic and Atmospheric Administration National Hurricane Center Report AL092008, 55 p.

Bonisteel, J., Nayegandhi, A., Brock, J.C., Wright, C.W., and Nagle, D.B., in press, Experimental Advanced Airborne Research Lidar (EAARL) data processing manual: U.S. Geological Survey OpenFile Report 0000-0000.

Brock, J.C., Wright, C.W., Sallenger, A., Krabill, W., and Swift, R., 2002, Basis and methods of NASA airborne topographic mapper lidar surveys for coastal studies: Journal of Coastal Research, vol. 18, no. 1, p. 1-13.

East, J.W., Turco, M.J., and Mason, R.R., Jr., 2008, Monitoring inland storm surge flooding from Hurricane Ike in Texas and Louisiana, September 2008: U.S. Geological Survey Open-File Report 2008-1365.

McGee, B.D., Goree, B.B., Tollett, R.W., Woodward, B.K., and Kress, W.H., 2006, Hurricane Rita surge data, southwestern Louisiana and southeastern Texas, September to November 2005: U.S. Geological Survey Data Series 220.

National Data Buoy Center, 2008, Reports from the National Data Buoy Center's stations during the passage of Hurricane Ike: National Oceanic and Atmospheric Administration, Accessed at http://www.ndbc.noaa.gov/hurricanes/2008/ike on February 10, 2009.

National Weather Service, 2008, Hurricane Ike storm surge estimates from damage surveys: National Oceanic and Atmospheric Administration, Accessed at http://www.srh.noaa.gov/hgx/projects/ike08/storm_surge_overview.htm on December 3, 2008.

Nayegandhi, A., Brock, J.C., and Wright, C.W., in press, Small-footprint, waveform-resolving lidar estimation of submerged and sub-canopy topography in coastal environments: International Journal of Remote Sensing.

Plant, N.G., Holland, K.T. and Puleo, J.A., 2002. Analysis of the scale of errors in nearshore bathymetric data: Marine Geology, vol. 191, p. 71-86.

Powell, M.D., Houston, S.H., Amat, L.R., and Morisseau-Leroy, N., 1998, The HRD real-time hurricane wind analysis system: Journal of Wind Engineering and Industrial Aerodynamics, vol. 77 78, p. 53-64.

Sallenger, A., Krabill, W.B., Swift, R.N., Brock, J., List, J., Hansen, M., Holman, R.A., Manizade, S., Sontag, J., Meredith, A., Morgan, K., Yunkel, J., Frederick, E., and Stockdon, H., 2003, Evaluation of airborne topographic lidar for quantifying beach changes: Journal of Coastal Research, vol. 19 , no. 1, p. $125-133$. 
Stockdon, H., Sallenger, A., List, J., and Holman, R., 2002, Estimation of shoreline position and change using airborne topographic lidar data: Journal of Coastal Research, vol. 18, no. 3, p. 502-513.

Stockdon, H.F., Doran, K.S., and Sallenger, A.H., in press, Extraction of lidar-based dune-crest elevations for use in examining the vulnerability of beaches to inundation during hurricanes: Journal of Coastal Research Special Issue.

Weber, K.M., List, J.H., and Morgan, K.L.M., 2005, An operational mean high water datum for determination of shoreline position from topographic lidar data: U.S. Geological Survey Open-File Report 2005-1027. 